IZA DP No. 6280

High on Life? Medical Marijuana Laws and Suicide

D. Mark Anderson

Daniel I. Rees

Joseph J. Sabia

January 2012 


\title{
High on Life? \\ Medical Marijuana Laws and Suicide
}

\author{
D. Mark Anderson \\ Montana State University \\ Daniel I. Rees \\ University of Colorado Denver \\ and IZA \\ Joseph J. Sabia \\ San Diego State University
}

Discussion Paper No. 6280
January 2012

IZA

P.O. Box 7240

53072 Bonn

Germany

Phone: +49-228-3894-0

Fax: +49-228-3894-180

E-mail: iza@iza.org

\begin{abstract}
Any opinions expressed here are those of the author(s) and not those of IZA. Research published in this series may include views on policy, but the institute itself takes no institutional policy positions.

The Institute for the Study of Labor (IZA) in Bonn is a local and virtual international research center and a place of communication between science, politics and business. IZA is an independent nonprofit organization supported by Deutsche Post Foundation. The center is associated with the University of Bonn and offers a stimulating research environment through its international network, workshops and conferences, data service, project support, research visits and doctoral program. IZA engages in (i) original and internationally competitive research in all fields of labor economics, (ii) development of policy concepts, and (iii) dissemination of research results and concepts to the interested public.
\end{abstract}

IZA Discussion Papers often represent preliminary work and are circulated to encourage discussion. Citation of such a paper should account for its provisional character. A revised version may be available directly from the author. 
IZA Discussion Paper No. 6280

January 2012

\section{ABSTRACT \\ High on Life? Medical Marijuana Laws and Suicide}

Using state-level data for the period 1990 through 2007, we estimate the effect of legalizing medical marijuana on suicide rates. Our results suggest that the passage of a medical marijuana law is associated with an almost 5 percent reduction in the total suicide rate, an 11 percent reduction in the suicide rate of 20- through 29-year-old males, and a 9 percent reduction in the suicide rate of 30- through 39-year-old males. Estimates of the relationship between legalization and female suicides are less precise and are sensitive to functional form.

JEL Classification: $\quad 110, I 18$

Keywords: medical marijuana laws, marijuana, alcohol, suicide

Corresponding author:

Daniel I. Rees

University of Colorado Denver

Department of Economics

Campus Box 181

P.O. Box 173364

Denver, CO 80217-3364

USA

E-mail: Daniel.Rees@ucdenver.edu 


\section{INTRODUCTION}

Under the Controlled Substances Act of 1970, marijuana was classified as a Schedule I drug because it was considered to have no "accepted medical use in treatment in the United States" (Eddy 2010). Since then, 16 states and the District of Columbia have legalized the use of medical marijuana; six more state legislatures have recently considered medical marijuana bills.

The relationship between marijuana and mental health has received a great deal of attention from both proponents and opponents of legalization. Proponents argue that marijuana can be an effective treatment for bipolarism, depression, and other mood disorders (Rosenthal et al. 1996; Grinspoon and Bakalar 1997; Zimmerman 1999). ${ }^{1}$ They also argue that medical marijuana patients are able to reduce their use of pain killers, tranquilizers, and psychiatric medicines because of marijuana (Lucido 2004). ${ }^{2}$

Opponents, on the other hand, argue that marijuana use increases the likelihood of depression, anxiety, psychosis, and schizophrenia (Zammit et al. 2002; Henquet et al. 2004; Goldberg 2006; Shulman 2008). They also argue that the negative effects of marijuana are long-lasting and that users are at risk of suffering from decreased psychological well-being later in life (Green and Ritter 2000; McGee et al. 2000).

This paper examines the relationship between medical marijuana laws (hereafter MMLs) and suicides. While the majority of people who suffer from mental illness do not commit suicide, over 90 percent of those who do commit suicide have a diagnosable mental or substance use disorder (Moscicki 2001). The relationship between marijuana

\footnotetext{
${ }^{1}$ Tetrahydrocannabinol (THC), the primary psychoactive ingredient in marijuana, produces mild euphoria and has analgesic effects (Elphick and Egertova 2001).

${ }^{2}$ Among some advocates, marijuana is referred to as "green Prozac" (Chaboya-Hembree 2011).
} 
use and suicide-related outcomes (e.g., depression, suicidal ideation, and suicide attempts) has been studied extensively (Petronis et al. 1990; Felts et al. 1992; Borowsky et al. 2001), but there have been no previous attempts to estimate the effect of medical marijuana laws on completed suicides, the tenth leading cause of death in the United States (National Institute of Mental Health 2010).

This study begins by detailing the channels through which MMLs could impact the risk of suicide. We cite research from epidemiological and medical studies showing that marijuana use is associated with depression and suicidal ideation, although we note that any observed association between marijuana use and outcomes such as these could be driven by difficult-to-observe factors (Van Ours and Williams 2011) or simply reflect self-medication (Gruber et al. 1996; Rey et al. 2002). We also note that previous studies have found evidence to support the hypothesis that marijuana and alcohol are substitutes (Chaloupka and Laixuthai 1997; Saffer and Chaloupka 1999; DiNardo and Lemieux 2001; Anderson et al. 2011; Crost and Guerrero 2011), and cite research linking alcohol policies and suicides (Birckmayer and Hemenway 1990; Jones et al. 1992; Markowitz et al. 2003; Carpenter 2004; Carpenter and Dobkin 2009).

The empirical analysis draws on data from the Centers for Disease Control from 1990 through 2007 to estimate the effect of legalization on suicide rates. Our results suggest that the passage of a MML is associated with an almost 5 percent reduction in the total suicide rate.

When we examine the relationship between legalization and suicides by gender and age, we find evidence that MMLs are associated with decreased suicides among 20through 29-year-old males and among 30- through 39-year-old males. This result is 
consistent with registry data from Arizona, Colorado, and Montana showing that most medical marijuana patients are male, and that roughly half are under the age of 40 (Anderson et al. 2011). Estimates of the relationship between legalization and suicides among females are less precise, and are sensitive to functional form. We conclude that the legalization of medical marijuana leads to an improvement in the psychological wellbeing of young adult males, an improvement that is reflected in fewer suicides.

\section{BACKGROUND}

\subsection{MMLs and substance use}

MMLs remove criminal penalties for using, possessing, and cultivating marijuana for medicinal purposes. Because it is prohibitively expensive for the government to ensure that all marijuana ostensibly grown for the medicinal market ends up in the hands of registered patients, diversion to the illegal market likely occurs. ${ }^{3}$ Only a handful of MMLs permit individuals with mental health problems to obtain medical marijuana. California includes anxiety as a qualifying condition, while Delaware and New Mexico both allow the use of medical marijuana for post traumatic stress disorder (Marijuana Doctors 2011). However, without exception, MMLs allow patients to register based on medical conditions that cannot be objectively confirmed (e.g., chronic pain and nausea), and in some states it is possible to petition for access to medical marijuana based on ailments not included on the official list of qualifying conditions (Marijuana Doctors 2011).

\footnotetext{
${ }^{3}$ All MMLs enacted during the period 1990-2007 allowed for home cultivation. Since 2007, Delaware, New Jersey and Washington D.C. have passed MMLs that do not permit home cultivation (Marijuana Policy Project 2011).
} 
Surprisingly little is known about the relationship between MMLs and marijuana use. Gorman and Huber (2007) examined data on adult arrestees for the period 19952002 from Denver, Los Angeles, Portland, San Diego and San Jose. They found little evidence that marijuana use by arrestees increased as a result of legalization. In contrast, Wall et al. (2011) found that rates of marijuana use among 12-through 17-year-olds were higher in states that had legalized medical marijuana than in states that had not, but noted that "in the years prior to MML passage, there was already a higher prevalence of use and lower perceptions of risk" in states that had legalized medical marijuana.

Perhaps the best evidence on the relationship between MMLs and marijuana use comes from Anderson et al. (2011). These authors used a difference-in-differences estimation strategy and data from the National Survey on Drug Use and Health (NSDUH) from three states that legalized medical marijuana in the mid-2000s: Montana, Rhode Island, and Vermont. They found that marijuana use among 18- through 25-year-olds living in Montana increased by 19 percent as a result of legalization. Marijuana use among 18- through 25-year-olds living in Rhode Island increased by 21 percent, and marijuana use by Rhode Island residents ages 26 and older increased by 44 percent. However, there was no evidence that legalization in Vermont led to an increase in consumption. $^{4}$

Anderson et al. (2011) also examined the relationship between MMLs and alcohol consumption. Using data from the Fatal Accident Report System (FARS) for the period 1990-2009, they found that legalization of medical marijuana led to a sharp reduction in

\footnotetext{
${ }^{4}$ Vermont passed a MML in 2004, but did not allow for medical marijuana dispensaries until 2011. This likely explains Anderson et al.'s (2011) null finding for Vermont.
} 
fatal crashes involving alcohol. In addition, using data from the Behavioral Risk Factor

Surveillance System (BRFSS) for the same period, they found evidence that legalization

led to a 25 percent reduction in self-reported alcohol consumption among 20- through 29-

year-olds; using data from the Beer Institute, they found that legalization led to a 5.3

percent decrease in per capita beer sales, the most popular alcoholic beverage among

young adults (Jones 2008). ${ }^{5}$ Anderson et al. (2011) concluded that their results were

“consistent with the hypothesis that marijuana and alcohol are substitutes" (p. 18). ${ }^{6}$

\subsection{Stressful life events and suicide}

Hamermesh and Soss (1974) were the first economists to model suicidal behavior. According to their "economic theory of suicide", negative shocks to happiness can reduce expected lifetime utility to the point where an individual will decide to take his or her own life. Even if a shock is perceived to be temporary, an individual with "timeinconsistent preferences" may commit suicide at the prospect of having to cope with an acutely "painful state in the present" (Cutler et al. 2001, p. 235). ${ }^{7}$

In fact, there is evidence that suicide among adolescents and young adults is often triggered by "stressful life events", or SLEs. SLEs include the breakup of a romantic

\footnotetext{
${ }^{5}$ Estimates from Anderson et al. (2011) on the relationship between MMLs and alcohol consumption are reproduced in Appendix Tables 2 and 3.

${ }^{6}$ Anderson et al. (2011) noted that a consensus has not been reached with regard to the relationship between marijuana and alcohol consumption. A number of studies have found evidence of complementarity between marijuana and alcohol (Pacula 1998; Farrelly et al. 1999; Williams et al. 2004; Yörük and Yörük 2011), while others studies lend support to the hypothesis that marijuana and alcohol are substitutes (Chaloupka and Laixuthai 1997; Saffer and Chaloupka 1999; DiNardo and Lemieux 2001; Crost and Guerrero 2011).

${ }^{7}$ There is evidence to support the hypothesis that preferences are time inconsistent (O'Donoghue and Rabin 2001, p. 41). Non-economists have exerted considerable effort to understand the rationality (or lack thereof) of suicide. See, for instance, Henry and Short (1954), Brandt (1975) and Graber (1981).
} 
relationship (De Wilde et al. 1992; Brent et al. 1993; Beautrais et al. 1997; Johnson et al. 2002), conflict with a parent or sibling (Brent et al. 1993; Johnson et al. 2002), an abortion (Gissler, Hemminki, and Lonnqvist 1996; Gissler et al. 2005), and legal/disciplinary problems (Brent et al. 1993).

Among older adults, problems at work, financial difficulties, unemployment and separation/divorce are common triggers of suicide (Heikkinen et al. 1994; Johansson and Sundquist 1997; Cavanagh et al. 1999; Preti and Miotto1999; Duberstein et al. 2004; Kõlves et al. 2006). Among the elderly, suicide is often associated with physical illness and functional impairment (Whitlock 1986; Mackenzie and Popkin 1987; Harris and Barraclough 1994; Conwell et al 2000; Waern et al. 2002). A number of researchers have concluded that the symptoms of depression (or self-reported depression) mediate the relationship between SLEs and suicidal behavior (Fergusson et al. 2000; Conwell et al. 2002; Hardt and Johnson 2010).

\subsection{Marijuana use and mental health}

Could marijuana use help individuals cope with the negative shocks to happiness that, according to Hamermesh and Soss (1974), lead to suicide? Alternatively, could marijuana use magnify the impact of SLEs?

Animal studies provide evidence that, at low doses, synthetic cannabinoid injections can have a potent anti-depressant effect (Jiang et al. 2005; Bambico et al. 
2007). However, higher dosages can reduce serotonin transmission and lead to "depression-like behavior" (Bambico et al. 2007; Bambico et al. 2010). ${ }^{8}$

The majority of epidemiological studies have found that marijuana use is positively associated with both the symptoms of depression and suicidal ideation (Rey et al. 2002; Moore et al. 2007). ${ }^{9}$ However, any association between marijuana use and outcomes such as these could be driven by difficult-to-observe factors (Van Ours and Williams 2011) or simply reflect self-medication (Gruber et al. 1996; Rey et al. 2002). Although there have been attempts to account for these sources of endogeneity, none have been particularly convincing. Moore et al. (2007, p. 325) concluded their review of the literature by noting that "the majority of studies for affective outcomes [such as depression and suicidal ideation] did not adequately address the problem of reverse causation as a possible alternative explanation for any association observed."

\subsection{Alcohol use and mental health}

Alcohol consumption represents an alternative route through which legalization of medical marijuana could impact suicides. Numerous studies have shown that alcoholism is more common among individuals with major depression (Sullivan et al. 2004).

\footnotetext{
${ }^{8}$ Deficiency of the neurotransmitter serotonin, a chemical produced by the brain, is linked to depression (Karg et al. 2011).

${ }^{9}$ For instance, Bovasso (2001) found that marijuana use was positively associated with these outcomes among Baltimore residents who participated in the Epidemiologic Catchment Area Study; Fergusson et al. (2002) found similar results among teenagers and young adults in New Zealand. In contrast, Denson and Earleywine (2006) found a negative association between marijuana use and the symptoms of depression. Beautrais et al. (1999) found that "much of the association between cannabis abuse/dependence and suicide attempt risk arose because: (a) individuals who develop cannabis abuse/dependency tend to come from disadvantaged socio-demographic and childhood backgrounds..., or (b) because cannabis abuse/dependence is co-morbid with other mental disorders which are independently associated with suicidal behaviour." Moore (2007) described the case of one woman who "without the relief that marijuana delivered to her...killed herself at home".
} 
Moreover, alcoholism is associated with suicidal ideation as well as attempted and completed suicides (Cornelious et al. 1995; Kessing 1999; Chatterji et al. 2004;

Rodriguez Andres 2005).

Policy studies provide further evidence of a link between alcohol use and suicide. For instance, Birckmayer and Hemenway (1990) and Carpenter and Dobkin (2009) provide evidence that prohibiting young adults from drinking protects against suicide. In a similar vein, Carpenter (2004) found that the adoption of stricter drunk driving laws lead to fewer suicides among young males. Markowitz et al. (2003) found a strong negative relationship between the excise tax on beer and male suicides. ${ }^{10}$ Interestingly, neither Carpenter (2004) nor Markowitz et al. (2003) found consistent evidence that alcohol policies had an impact on female suicides.

\section{SUICIDE, TRENDS AND DATA}

Data on suicides come from the National Center for Health Statistics Mortality Detail Files, produced by the Centers for Disease Control. ${ }^{11}$ Table 1 shows the number of suicides per 100,000 population by age and gender for the period under study, 19902007.

Females suffer from depression and attempt suicide at higher rates than males (Murphy 1998). ${ }^{12}$ Nevertheless, males are approximately four times more likely to

\footnotetext{
${ }^{10}$ See also Son and Topyan (2011), who examined the relationship between alcoholic beverage excise taxes and suicides using data from the United States for the period 1995-2004.

${ }^{11}$ As pointed out by Birckmayer and Hemenway (1999) and Carpenter (2004), suicides are likely underreported in these data. However, there is no reason to believe that this underreporting is systematically related to the legalization of medical marijuana.

${ }^{12}$ Murphy (1998) argued that females are less likely to commit suicide than males because they are more likely to seek treatment for depression.
} 
commit suicide. Since 1990, the male suicide rate has decreased slightly, while the female suicide rate has remained fairly constant (Figure 1).

Fifteen- through 19-year-olds were less likely to commit suicide than older individuals during the period under study; males over the age of 59 were the most likely to commit suicide (Figures 2 and 3). Canetto (1992) argued that, as they age, men are especially prone to suicide because they have unrealistic expectations and an inadequate range of coping strategies. Clarke (1993, p. 21) hypothesized that "elderly persons who die by suicide have a lifelong character fault that remains invisible until aging lifechanges force the issue into the open."

Figures 4 through 14 illustrate suicide trends by legalization status. ${ }^{13}$ For states that legalized medical marijuana, we report the suicide rate for the three years prior to legalization, the year in which the law changed (year 0), and the three years following legalization. For states that did not legalize medical marijuana during the period under study, the year in which the law changed was randomly assigned.

Figure 4 presents pre- and post-legalization trends in the total suicide rate. The total suicide rate falls smoothly during the pre-legalization period in both MML and nonMML states. However, beginning in year 0 , the trends diverge: the suicide rate in MML states continues to fall, while the suicide rate in states that never legalized medical marijuana begins to climb gradually. Comparing Figures 5 and 6, it is clear that the postlegalization downward trend in male suicides is much more pronounced than the postlegalization downward trend in female suicides.

\footnotetext{
${ }^{13}$ In each figure, a vertical line separates the years before legalization from the year of the law change and the post- legalization period.
} 
Consistent with the hypothesis that marijuana can be an effective treatment for depression and other mood disorders, there appears to be a sharp decrease in the suicide rate of 15-through 19-year olds males in the treatment states as compared to the control states approximately two years after legalization (Figure 7). A similar decrease can be seen for 20- through 59-year-old males (Figures 8 and 9), and there is a modest decrease in the suicide rate of males 60 years of age and older approximately three years after legalization (Figure 10). Among females under the age of 40, there is little evidence that legalization lead to a decrease in the suicide rate (Figures 11 and 12). However, among older females, there appears to be a small decrease in the suicide rate two to three years after legalization (Figures 13 and 14).

\section{THE EMPIRICAL MODEL}

The trends discussed above could be driven by a number of factors such as statelevel economic conditions or alcohol policies. In order to address this shortcoming, we use a difference-in-differences (DD) regression framework to estimate the relationship between MMLs and suicide rates. This framework allows us to control for both unobserved state-level heterogeneity and national trends. Our baseline estimating equation is:

$$
\ln \left(\text { Suicides } \text { Total }_{s t}\right)=\beta_{0}+\beta_{1} M M L_{s t}+\boldsymbol{X}_{s t} \boldsymbol{\beta}_{2}+v_{s}+w_{t}+\varepsilon_{s t}
$$

where $s$ indexes states, $t$ indexes years, and $v_{s}$ and $w_{t}$ represent state and year fixed effects, respectively. The variable $M M L_{s t}$ is an indicator for whether medical marijuana 
was legal in state $s$ and year $t$. The coefficient of interest, $\beta_{1}$, represents the effect of medical marijuana legislation. In alternative specifications we replace Suicides Total $_{s t}$ with the other dependent variables listed in Table 1 and add state-specific linear time trends to the right-hand side. ${ }^{14}$ The state-specific trends are intended to control for the influence of difficult-to-measure factors at the state level that evolve smoothly over time such as attitudes. ${ }^{15}$

The vector $\boldsymbol{X}_{\boldsymbol{s}}$ includes indicators for whether Zero Tolerance drunk driving and 0.08 BAC laws were enforced in state $s$ and year $t$, and the state beer tax. Previous studies provide evidence that stricter alcohol policies and higher beer taxes can reduce suicides (e.g., Jones et al. 1992; Birckmayer and Hemenway 1999; Markowitz et al. 2003; Carpenter 2004). ${ }^{16}$ In addition, the vector $\boldsymbol{X}_{\text {st }}$ includes the state unemployment rate and income per capita. ${ }^{17}$ Previous studies have shown that suicide rates are sensitive to economic conditions (Gerdtham and Johannesson 2003; Andres 2005; Minoiu and Rodriguez Andres 2008; Chung 2009). Finally, we control for whether marijuana use and possession was decriminalized. ${ }^{18}$

\footnotetext{
${ }^{14}$ In other words, we include an interaction between the state dummies and a variable equal to 1 in 1990,2 in 1991, 3 in 1993, and so forth.

${ }^{15}$ DeCicca et al. (2008) found that attitudes toward cigarette smoking were an important determinant of youth smoking participation.

${ }^{16}$ Data on the Zero Tolerance laws, 0.08 BAC laws, and beer taxes are from the National Highway Traffic Safety Administration, Freeman (2007), and the Beer Institute, respectively. Jones et al. (1992) and Birckmayer and Hemenway (1999) both found that higher minimum legal drinking ages (MLDA) were associated with fewer youth suicides. Carpenter and Dobkin (2009) used a regression discontinuity design to show that granting legal access to alcohol at age 21 leads to a large and immediate increase in suicides. But, because all states had a minimum legal drinking age of 21 by 1990, we do not control for the MLDA.

${ }^{17}$ The unemployment and income data are from the Bureau of Labor Statistics and the Bureau of Economic Analysis, respectively.

${ }^{18}$ During the period $1990-2007$, the decriminalization indicator only captures one policy change: Nevada decriminalized marijuana in 2001. The majority of these laws were passed prior to 1990 .
} 


\subsection{The baseline results}

\section{THE RESULTS}

Table 2 presents OLS estimates of the relationship between MMLs and suicides. All regressions are weighted by the relevant population in state $s$ and year $t$, and the standard errors are corrected for clustering at the state level (Bertrand et al. 2004).

The estimated relationship between MMLs and the total suicide rate is presented in the first column of Table 2. Controlling for year and state fixed effects, the legalization of medical marijuana is associated with an 8.1 percent decrease in the suicide rate $\left(\mathrm{e}^{-0.084}-1=-0.081\right)$. When the controls listed in Table 1 are included, legalization is associated with a 6.9 percent decrease in the suicide rate; when state-specific linear time trends are included, legalization is associated with a 4.8 percent decrease in the suicide rate.

In the remaining columns of Table 2 , we allow the estimated relationship between legalization and suicides to differ by gender. MMLs are associated with a 4.6 to 7.0 percent decrease in the male suicide rate. MMLs are negatively associated with the female suicide rate, but these estimates are not statistically significant at conventional levels.

\subsection{Estimates by gender and age group}

Next, we examine the relationship between the legalization of medical marijuana and suicides by age group (Table 3). Our estimates suggest that legalization leads to a sharp reduction in suicides among young adult males. For instance, in the fully-specified model, legalization is associated with a 10.8 percent decrease in the suicide rate of 20through 29-year-old males, and a 9.4 percent decrease in the suicide rate of 30 - through 
39-year-old males. These results are consistent with those of Anderson et al. (2011), who found that MMLs have the greatest impact on the substance use of young adults, and are also consistent with registry data from Arizona, Colorado, and Montana showing that most medical marijuana patients are male and that roughly half of medical marijuana patients are under the age of 40 (Anderson et al. 2011).

Although the estimates of $\beta_{1}$ are negative for males between the ages of 15 and 19, they are never significantly different from zero. Likewise, the estimates of $\beta_{1}$ for males ages 40 through 59 are consistently negative, but not precisely estimated. For males 60 years of age and older, estimates are negative in two of the three specifications, but none are precisely estimated.

Table 4 presents the results for females by age group. There is little evidence that legalization of medical marijuana impacted suicides among females under the age of 30 . The estimated relationship between legalization and suicides is stronger among older females, although it is sensitive to model specification. Controlling for state and year fixed effects and the covariates listed in Table 1, the legalization of medical marijuana is associated with a 10.4 percent decrease in the suicide rate of 30- through 39-year-old females. However, the estimated impact of legalization becomes much smaller in magnitude and is no longer statistically significant when we add state-specific linear time trends.

Although consistently negative, the estimated impact of legalization for females ages 40 through 49 is never statistically significant. However, when we control for statespecific linear time trends, legalization is associated with large and statistically 
significant decreases in the suicide rate of 50-through 59-year-old females and the suicide rate of females ages 60 and older.

\subsection{Adding leads and lags to the model}

In Table 5 we examine pre- and post-legalization trends in suicides using the regression framework introduced above. Specifically, we include three lead indicators, an indicator for the year of the law change, and four lag indictors. The omitted category is $3+$ years before a MML was passed.

The results are consistent with the hypothesis that MMLs have a causal impact on male suicide rates. Controlling for year and state fixed effects, the covariates listed in Table 1 and state-specific linear trends, none of the lead dummies are statistically distinguishable from zero. However, once a MML is passed, there is a strong negative relationship between legalization and the male suicide rate.

In contrast, the evidence that legalization reduces suicides among females is much weaker. The estimated coefficients of the three lead indicators are large, negative, and statistically significant, suggesting that there was a systematic change in the suicidal behavior of females preceding legalization. Although the estimated coefficients of the lag indicators are two to three times larger than those of the lead indicators, we cannot reject the hypothesis that they are equal. ${ }^{19}$

\subsection{A placebo test}

\footnotetext{
${ }^{19}$ As noted above, Carpenter (2004) found evidence that Zero Tolerance drunk driving laws were negatively associated with male suicides. He also found evidence of an implausibly large (and statistically significant) relationship between Zero Tolerance drunk driving laws and female suicides.
} 
Lastly, we performed a robustness check based on Luallen (2006). ${ }^{20}$ Specifically, we generated a placebo MML indicator using a random number generator based on the continuous uniform distribution. Because 12 states passed a MML during our sample period, we assigned 12 placebo policies for each trail run. ${ }^{21}$ In total, 50 trials were run.

Table 6 illustrates the average coefficient estimates for the placebo MML on total, male and female suicide rates. In all three sets of regressions, the average estimate is quite small in magnitude. Moreover, in 50 trials, only four estimates were negative and statistically significant at the 5 percent level for the total suicide rate. For male and female suicide rates, only three and four of the estimates were negative and statistically significant at the 5 percent level, respectively. This pattern of results provides evidence that our estimates cannot be readily reproduced through random assignment of legalization.

\section{CONCLUSION}

Numerous epidemiological studies have found a positive association between marijuana and suicide-related outcomes such as depression and suicidal ideation. However, this association could be driven by difficult-to-observe factors or simply reflect self-medication. In fact, a recent review of the epidemiological literature concluded that most studies had not adequately addressed the problem of reverse causation (Moore et al. 2007).

\footnotetext{
${ }^{20}$ Luallen (2006) examined the relationship between teacher strike days and juvenile crime.

${ }^{21}$ A year of legalization between 1990 and 2007 was randomly selected. Randomly assigning a legalization year between 1999 and 2007 produced qualitatively similar results.
} 
The current study avoids the problems of reverse causality and unobserved heterogeneity at the individual level by examining the relationship between the legalization of medical marijuana and completed suicides. Specifically, we use a difference-in-differences empirical strategy to estimate the impact of MMLs on statelevel suicide rates. Our results suggest that the legalization of medical marijuana is associated with a 5 percent decrease in the total suicide rate, an 11 percent decrease in the suicide rate of 20- through 29-year-old males, and a 9 percent decrease in the suicide rate of 30- through 39 year-old-males. Estimates for female suicide rates are generally measured with less precision and are sensitive to functional form.

In an often-cited article, Hamermesh and Soss (1974) argued that negative shocks to happiness may reduce expected lifetime utility to the point where an individual will decide to take his or her own life. The negative relationship between legalization and suicides among young adult males is consistent with the argument that marijuana can be used to cope with such shocks. However, estimates provided by Anderson et al. (2011) provide an alternative explanation. These authors found that the passage of MMLs led to sharp decreases in alcohol-related traffic fatalities, self-reported alcohol use, and per capita beer sales. The strong association between alcohol consumption and suiciderelated outcomes found by previous researchers (Markowitz et al. 2003; Carpenter 2004; Sullivan et al. 2004; Rodriguez Andres 2005; Carpenter and Dobkin 2009) raises the possibility that medical marijuana laws reduce the risk of suicide by decreasing alcohol consumption.

Although 16 states have passed medical marijuana laws, and others are considering legalization, very little is known about the effects of these laws. 
Policymakers weighing the pros and cons of legalization should consider the possibility that medical marijuana laws may lead to fewer suicides among young adult males.

However, the exact mechanism through which suicides are reduced remains a topic for future study.

\section{REFERENCES}

Anderson, D. Mark, Daniel I. Rees, and Benjamin Hansen. 2011. "Medical Marijuana Laws, Traffic Fatalities, and Alcohol Consumption.” Working Paper, Montana State University.

Bambico, Francis Rodríguez, Noam Katz, Guy Debonnel, and Gabriella Gobbi. 2007. "Cannabinoids Elicit Antidepressant-Like Behavior and Activate Serotonergic Neurons through the Medial Prefrontal Cortex." Journal of Neuroscience 27: 11700-11711.

Bambico, Francis Rodrigues, Nhu-Tram Nguyen, Noam Katz, and Gabriella Gobbi. 2010. "Chronic Exposure to Cannabinoids during Adolescence but Not during Adulthood Impairs Emotional Behaviour and Monoaminergic Neurotransmission." Neurobiology of Disease 37: 641-655.

Beautrais, Annette, Peter Joyce, and Roger Mulder. 1997. "Precipitating Factors and Life Events in Serious Suicide Attempts Among Youths Aged 13 Through 24 Years." Journal of the American Academy of Child \& Adolescent Psychiatry 36: 1543-1551.

Beautrais, Annette, Peter Joyce, and Roger Mulder. 1999. "Cannabis Abuse and Serious Suicide Attempts." Addiction 94: 1155-1164.

Bertrand, Marianne, Esther Duflo, and Sendhil Mullainathan. 2004. "How Much Should We Trust Differences-in-Differences Estimates?" Quarterly Journal of Economics 119: 249-276.

Birckmayer, Johanna, and David Hemenway. 1999. "Minimum-Age Drinking Laws and Youth Suicide, 1970-1990." American Journal of Public Health 89: 1365-1368.

Borowsky, Iris, Marjorie Ireland, and Michael Resnick. 2001. "Adolescent Suicide Attempts: Risks and Protectors." Pediatrics 107: 485-493.

Bovasso, Gregory. 2001. "Cannabis Abuse as a Risk Factor for Depressive Symptoms." American Journal of Psychiatry 158: 2033-2037. 
Brandt, Richard. 1975. "The Morality and Rationality of Suicide.” In Seymour Perlin, ed., A Handbook for the Study of Suicide. Oxford: Oxford University Press.

Brent, David, Joshua Perper, Grace Moritz, Marianne Baugher, Claudia Roth, Lisa Balach, and Joy Schweers. 1993. "Stressful Life Events, Psychopathology, and Adolescent Suicide: A Case Control Study.” Suicide and Life-Threatening Behavior 23: 179-187.

Canetto, Silvia. 1992. "Gender and Suicide in the Elderly." Suicide and LifeThreatening Behavior 22: 80-97.

Carpenter, Christopher. 2004. "Heavy Alcohol Use and Youth Suicide: Evidence from Tougher Drunk Driving Laws." Journal of Policy Analysis and Management 23: 831-842.

Carpenter, Christopher, and Carlos Dobkin. 2009. "The Effect of Alcohol Consumption on Mortality: Regression Discontinuity Evidence from the Minimum Drinking Age." American Economic Journal: Applied Economics 1: 164-182.

Cavanagh, J.T.O., D.G.C. Owens, and E.C. Johnstone. 1999. "Life Events in Suicide and Undetermined Death in South-East Scotland: A Case-Control Study using the Method of Psychological Autopsy." Social Psychiatry and Psychiatric Epidemiology 34: 645-650.

Chaboya-Hembree, Jan. 2011. "Medical Marijuana as a Treatment for Depression." Available at: http://medicalmarijuana.com/experts/expert/title.cfm? artID=65.

Chatterji, Pinka, Daval Dave, Robert Kaestner, and Sara Markowitz. 2004. "Alcohol Abuse and Suicide Attempts among Youth.” Economics and Human Biology 2: 159-180.

Chung, Andy. 2009. "Gender Difference in Suicide, Household Production and Unemployment.” Applied Economics 41: 2495-2504.

Conwell Y., J.M. Lyness, P. Duberstein, C. Cox, L. Seidlitz, A. DiGiorgio, and E.D. Caine. 2000. "Completed suicide among older Patients in Primary Care Practices: A Controlled Study." Journal of the American Geriatrics Society Soc 48: 23-29.

Conwell, Y, P.R. Duberstein, and E.D. Caine. 2002. "Risk Factors for Suicide in Later Life." Biological Psychiatry 52:193-204.

Cornelius, Jack, I. Salloum, J. Mezzich, Marie Cornelius, Horacio Fabrega, Jr., J. Ehler, 
R. Ulrich, M. Thase, and J. Mann. 1995. "Disproportionate Suicidality in Patients with Comorbid Major Depression and Alcoholism." American Journal of Psychiatry 152: 358-364.

Cutler, David, Edward Glaeser, and Karen Norberg. 2001. "Explaining the Rise in Youth Suicide." In Jonathan Gruber, ed., Risky Behavior among Youths: An Economic Analysis. Chicago, IL: University of Chicago Press.

DeCicca, Philip, Donald Kenkel, Alan Mathios, Yoon-Jeong Shin, and Jae-Young Lim. 2008. "Youth Smoking, Cigarette Prices, and Anti-Smoking Sentiment." Health Economics 17: 733-749.

Denson, Thomas and Mitchell Earleywine. 2006. "Decreased Depression in Marijuana Users." Addictive Behaviors 31: 738-742.

De Wilde, E., I. Kienhorst, R. Diekstra, and W. Wolters 1992. "The Relationship between Adolescent Suicidal Behavior and Life Events in Childhood and Adolescence." American Journal of Psychiatry 149: 45-51.

Duberstein, P. R., Y. Conwell, K.R. Conner. S. Eberly, and E.D. Caine. 2004. "Suicide at 50 Years of Age and Older: Perceived Physical Illness, Family Discord and Financial Strain.” Psychological Medicine, 34: 137-146.

Eddy, Mark. 2010. "Medical Marijuana: Review and Analysis of Federal and State Policies." Congressional Research Service Report for Congress. Available at: http://www.fas.org/sgp/crs/misc/RL33211.pdf.

Elphick, Maurice and Michaela Egertova. 2001. "The Neurobiology and Evolution of Cannabinoid Signalling." Philosophical Transactions of the Royal Society B: Biological Sciences 356: 381-408.

Felts, W. Michael, Thomas Chenier, and Robert Barnes. 1992. "Drug Use and Suicide Ideation and Behavior among North Carolina Public School Students." American Journal of Public Health 82: 870-872.

Fergusson, David M., Annette Beautrais, and L. John Horwood. 2003. "Vulnerability and Resiliency to Suicidal Behaviours in Young People." Psychological Medicine 33: 61-73.

Fergusson, David M., L. John Horwood, and Nicola Swain-Campbell. 2002. "Cannabis Use and Psychosocial Adjustment in Adolescence and Young Adulthood." Addiction 97: 1123-1135.

Fergusson, David M., L. J. Woodward., and L. J. Horwood. 2000. "Risk Factors and Life Processes Associated with the Onset of Suicidal Behaviour during Adolescence and Early Adulthood." Psychological Medicine 30: 23-39. 
Freeman, Donald. 2007. "Drunk Driving Legislation and Traffic Fatalities: New Evidence on BAC 08 Laws." Contemporary Economic Policy 25: 293-308.

Gerdtham, Ulf-G. and Magnus Johannesson. 2003. "A Note on the Effect of Unemployment on Mortality." Journal of Health Economics 22: 505-518.

Gissler, Mika, Cynthia Berg, Marie-Helene Bouvier-Colle, and Pierre Buekens. 2005. "Injury Deaths, Suicides and Homicides Associated with Pregnancy, Finland 1987-2000." European Journal of Public Health 15: 459-63.

Gissler, Mika, Elina Hemminki, and Jouko Lonnqvist. 1996. "Suicides after Pregnancy in Finland 1987-94: Register Linkage Study." British Medical Journal 313: 1431-1434.

Goldberg, Carey. 2006. "Studies Link Psychosis, Teenage Marijuana Use.” Boston Globe 26 January. Available at: http://www.boston.com/yourlife/health/children/articles/2006/01/26/studies_link_ psychosis_teenage_marijuana_use/.

Gorman, Dennis and Charles Huber Jr. 2007. "Do Medical Cannabis Laws Encourage Cannabis Use?” International Journal of Drug Policy 18: 160-167.

Graber, Glenn. 1981. "The Rationality of Suicide.” In Samuel Wallace and Albin Eser, eds., Suicide and Euthanasia: The Rights of Personhood. Knoxville: U. Tennessee Press.

Grinspoon, Lester and James Bakalar. 1997. Marihuana: The Forbidden Medicine. New Haven, CT: Yale University Press.

Gruber, Amanda, Harrison Pope, and Michael Brown. 1996. "Do Patients Use Marijuana as an Antidepressant?" Depression 4: 77-80.

Hardt, Jochen, and Jeffrey G. Johnson. 2010. "Suicidality, Depression, Major and Minor Negative Life Events: A Mediator Model." German Medical Science Psychosocial Medicine 7: Doc05.

Harris, E.C., and B.M. Barraclough. 1994. "Suicide as an Outcome for Medical Disorders." Medicine 73: 281-296.

Hamermesh, Daniel, and Neal Soss. 1974. "An Economic Theory of Suicide.” Journal of Political Economy 82: 83-98.

Heikkinen, M, H. Aro, and J. Lönnqvist. 1994. "Recent Life Events, Social Support and Suicide.” Acta Psychiatrica Scandinavica 89: 65-72.

Henry, Andrew, and James Short. 1954. Suicide and Homicide. Glencoe, IL: Free Press. 
Henquet, Cecile, Lydia Krabbendam, Janneke Spauwen, Charles Kaplan, Roselind Lieb, Hans-Ulrich Wittchen, and Jim van Os. 2005. "Prospective Cohort Study of Cannabis Use, Predisposition for Psychosis, and Psychotic Symptoms in Young People." British Medical Journal 330:11-15.

Jiang, Wen, Yun Zhang, Lan Xiao, Jamie Van Cleemput; Shao-Ping Ji, Guang Bai, and Xia Zhang. 2005. "Cannabinoids Promote Embryonic and Adult Hippocampus Neurogenesis and Produce Anxiolytic- and Antidepressant-Like Effects." Journal of Clinical Investigation 115: 3104-3116.

Johansson, S.E. and J. Sundquist. 1997. "Unemployment is an Important Risk Factor for Suicide in Contemporary Sweden: An 11-year Follow-up Study of a Crosssectional Sample of 37,789 People." Public Health 111: 41-45.

Johnson, Jeffrey, Patrick Cohen, Madelyn Gould, Stephanie Kasen, Jocelyn Brown, and Judith Brook. 2002. "Childhood Adversities, Interpersonal Difficulties, and Risk for Suicide Attempts during Late Adolescence and Early Adulthood." Archives of General Psychiatry 59: 741-749.

Jones, Jeffrey. 2008. "Beer Back to Double-Digit Lead Over Wine as Favored Drink." Gallup. 25 July. Available at: http://www.gallup.com/poll/109066/beer-back-doubledigit-lead-over-wine-f avored-drink.aspx.

Jones, Nancy, Carl Pieper, and Leon Roberston. 1992. "The Effect of Legal Drinking Age on Fatal Injuries of Adolescents and Young Adults." American Journal of Public Health 82: 112-115.

Karg, Katja, Margit Burmeister, Kerby Shedden, and Srijan Sen. 2011. "The Serotonin Transporter Promoter Variant (5-HTTLPR), Stress, and Depression Meta-analysis Revisted." Archives of General Psychiatry 68: 444-454.

Kessing, Lars Vedel. 1999. "The Effect of Comorbid Alcoholism on Recurrence in Affective Disorder: A Case Register Study.” Journal of Affective Disorders 53: 49-55.

Kõlves, Kairi, Airi Värnik, Barbara Schneider, Jürgen Fritze, and Jüri Allik. 2006. "Recent Life Events and Suicide: A Case-Control Study in Tallinn and Frankfurt." Social Science and Medicine 62: 2887-2896.

Lewinsohn, Peter, Paul Rohde, and John Seeley. 1994. "Psychosocial Risk Factors for Future Adolescent Suicide Attempts." Journal of Consulting and Clinical Psychology 62: 297-305.

Luallen, Jeremy. 2006. "School's Out...Forever: A Study of Juvenile Crime, At-Risk 
Youths and Teacher Strikes." Journal of Urban Economics 59: 75-103.

Lucido, Frank. 2004. "Implementation of the Compassionate Use Act in a Family Medicine Practice: Seven Years Clinical Experience.” Available at: http://www.medboardwatch.com.

Marijuana Doctors. 2011. "Medical Marijuana: Medical Marijuana Laws, Qualification Guidelines, and ID Card Information." Available at: https://www.marijuanadoctors.com/medical-marijuana/index.

Marijuana Policy Project. 2011. "Key Aspects of State and D.C. Medical Marijuana Laws." Available at: http://www.mpp.org/legislation/state-by-state-medical-marijuana-laws.html.

Markowitz, Sara, Pinka Chatterji, and Robert Kaestner. 2003. "Estimating the Impact of Alcohol Policies on Youth Suicides." Journal of Mental Health Policy and Economics 6: 37-46.

Marmor, Jane. 1998. “Medical Marijuana.” Western Journal of Medicine 168: 540-543.

Mackenzie, T.B. and M.K. Popkin. 1987. "Suicide in the Medical Patient." International Journal of Psychiatry in Medicine 17: 3-22.

McGee, Rob, Sheila Williams, Richie Poulton, and Terrie Moffitt. 2000. "A Longitudinal Study of Cannabis Use and Mental Health from Adolescence to Early Adulthood." Addiction 95: 491-503.

Minoiu, Camelia and Antonio Rodriguez Andres. 2008. "The Effect of Public Spending on Suicide: Evidence from U.S. State Data." Journal of Socio-Economics 37: 237-261.

Model, Karyn. 1993. "The Effect of Marijuana Decriminalization on Hospital Emergency Room Drug Episodes: 1975-1978.” Journal of the American Statistical Association 88: 737-747.

Moore, Michael. 2007. "Medical Marijuana User Commits Suicide After Long Being Denied Its Use." Missoulian 27 October. Available at: http://digg.com/news/story/Medical_Marijuana_User_Commits_Suicide_After_L ong_Being_Denied_Its_Use.

Moore, Theresa, Stanley Zammit, Anne Lingford-Hughes, Thomas Barnes, Peter Jones, Margaret Burke, and Glyn Lewis. 2007. "Cannabis Use and Risk of Psychotic or Affective Mental Health Outcomes: A Systematic Review." Lancet 370: 319-328. 
Moscicki, Eve. 2001. "Epidemiology of Completed and Attempted Suicide: Toward a Framework for Prevention." Clinical Neuroscience Research 1: 310-323.

Murphy, George. 1998. "Why Women Are Less Likely Than Men to Commit Suicide." Comprehensive Psychiatry 39: 165-175.

National Institute of Mental Health. 2010. "Suicide in the U.S.: Statistics and Prevention." 27 September. Available at:

http://www.nimh.nih.gov/health/publications/suicide-in-the-us-statistics-andprevention/index.shtml.

O’Donoghue, Ted and Matthew Rabin. 2001."Risky Behavior among Youths: Some Issues from Behavioral Economics.” In Jonathan Gruber, ed., Risky Behavior among Youths: An Economic Analysis. Chicago, IL: University of Chicago Press.

Pabst Battin, Margaret. 1996. The Death Debate: Ethical Issues in Suicide. Upper Saddle River, NJ: Prentice-Hall.

Petronis, K., J. Samuels, E. Moscicki, and J. Anthony. 1990. “An Epidemiologic Investigation of Potential Risk Factors for Suicide Attempts.” Social Psychiatry and Psychiatric Epidemiology 25: 193-199.

Preti, Antonia and Paola Miotto. 1999. "Suicide and Unemployment in Italy, 1982-1994. Journal of Epidemiology and Community Health 53: 694-701.

Reading, Anthony. 2004. Hope and Despair: How Perceptions of the Future Shape Human Behavior. Baltimore, MD: Johns Hopkins University Press.

Rey, Joseph, Michael Sawyer, Beverley Raphael, George Patton, and Michael Lynskey. 2002. "Mental Health of Teenagers Who Use Cannabis: Results of an Australian Survey." British Journal of Psychiatry 180: 216-221.

Rodriguez Andres, Antonio. 2005. "Income Inequality, Unemployment, and Suicide: A Panel Data Analysis of 15 European Countries.” Applied Economics 37: 439-451.

Rosenthal, Ed, Dale Gieringer, and Tod Mikuriya. 1996. Marijuana Medical Handbook: A Guide to Therapeutic Use. San Francisco, CA: Quick American Archives.

Scott, Emilee Mooney. 2010. "Marijuana Decriminalization.” Office of Legislative Research Report. Available at: http://www.cga.ct.gov/2010/rpt/2010-R-0204.htm.

Ross R.K., L. Bernstein, L. Trent, B.E. Henderson, and A. Paganini-Hill. 1990. “A 
Prospective Study of Risk Factors for Traumatic Death in the Retirement Community." Preventative Med 19: 323-334.

Shaffer, David, Madely Gould, Prudence Fisher, Paul Trautman, Donna Moreau, Marjorie Kleinman, and Michael Flory. 1996. "Psychiatric Diagnosis in Child and Adolescent Suicide." Archives General Psychiatry 53: 339-348.

Shulman, Matthew. 2008. "Marijuana Linked to Heart Disease and Depression." U.S. News 14 May. Available at: http://health.usnews.com/health-news/familyhealth/heart/articles/2008/05/14/marijuana-linked-to-heart-disease-anddepression.

Son, Chong Hwan and Kudret Topyan. 2011. "The Effect of Alcoholic Beverage Excise Tax on Alcohol-Attributable Injury Mortalities." European Journal of Health Economics 12: 103-113.

Sullivan, Lynn, David Fiellin, and Patrick O'Connor. 2004. "The Prevalence and Impact of Alcohol Problems in Major Depression: A Systematic Review.” American Journal of Medicine 118: 330-341.

Vaillant, George E. and Susan J. Blumenthal. 1990. "Introduction: Suicide Over the Life Cycle - Risk Factors and Life Span Development." In Susan J. Blumenthal and David J. Kupfer, eds., Suicide Over the Life Cycle: Risk Factors, Assessment, and Treatment of Suicidal Patients. Washington DC: American Psychiatric Press Inc.

Van Ours, Jan and Jenny Williams. 2011. "Cannabis Use and Mental Health Problems." Journal of Applied Econometrics 26: 1137-1156.

Wall, Melanie, Ernest Poh, Magdalena Cerdá, Katherine Keyes, Sandro Galea, and Deborah Hasin. 2011. "Adolescent Marijuana Use from 2002 to 2008: Higher in States with Medical Marijuana Laws, Cause Still Unclear." Annals of Epidemiology 21: 714-716.

Waern, Margda, Bo S. Runeson, Peter Allebeck, Jan Beskow, Eva Rubenowitz, Ingmar Skoog, and Katarina Wilhelmsson. 2002. "Mental Disorder in Elderly Suicides: A Case-Control Study.” American Journal of Psychiatry 159: 450-455.

Watson, Stanley, John Benson, Jr., and Janet Joy. 2000. "Marijuana and Medicine: Assessing the Science Base.” Archives of General Psychiatry 57: 547-552.

Whitlock, Francis. 1986. "Suicide and physical illness." In A. Roy, ed., Suicide. Baltimore: Williams \& Wilkins.

Zammit, Stanley; Peter Allebeck, Sven Andreasson, Ingvar Lundberg, and Glyn Lewis. 2002. "Self Reported Cannabis Use as a Risk Factor for Schizophrenia in Swedish Conscripts of 1969: Historical Cohort Study." British Medical Journal 
325: 1199-1203.

Zimmerman, Bill. 1999. Is Marijuana the Right Medicine for You? New York, NY: Pocket Books. 


\section{Figure 1. National Suicide Rates}

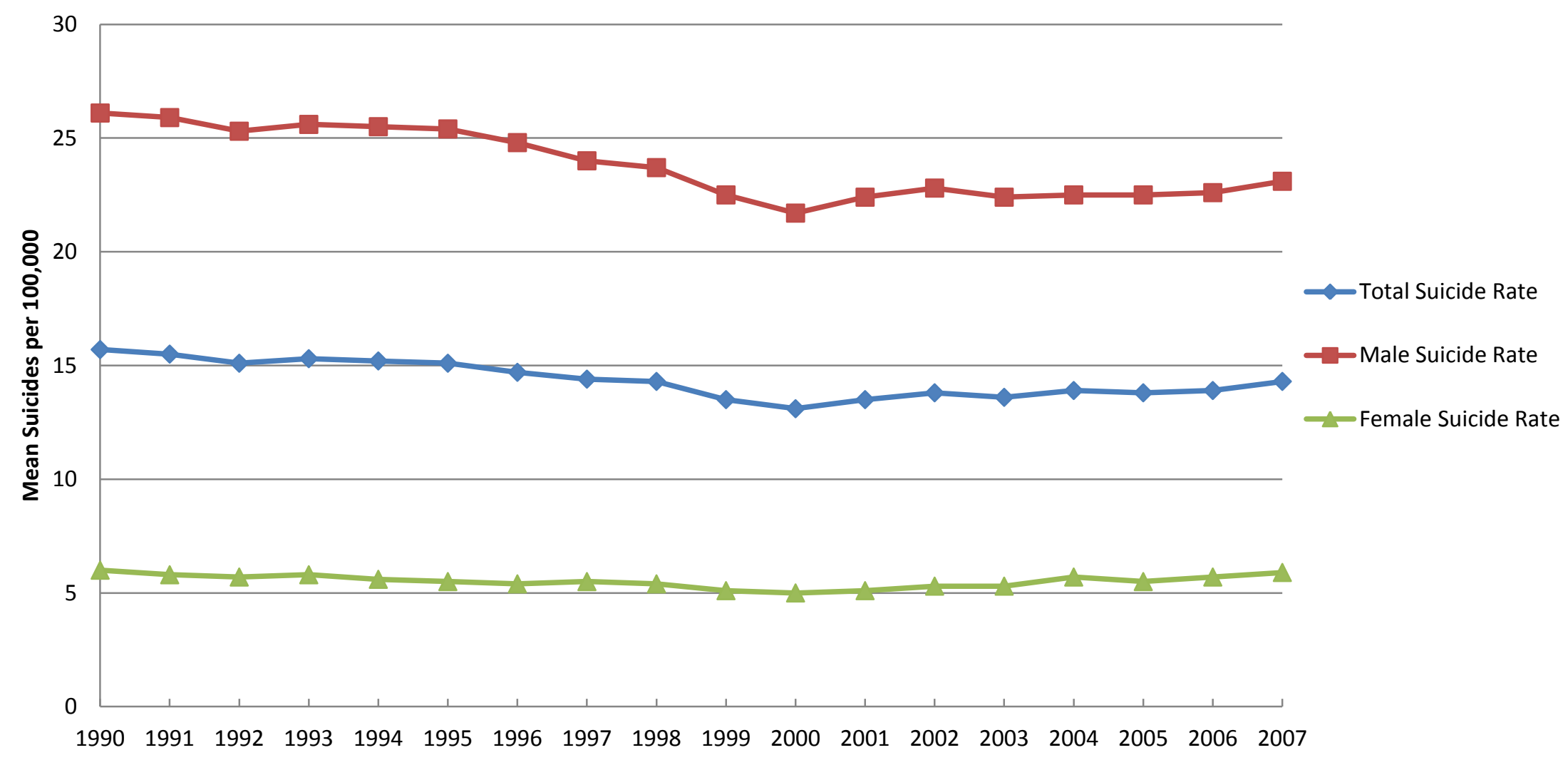




\section{Figure 2. National Suicide Rates by Age, Males}

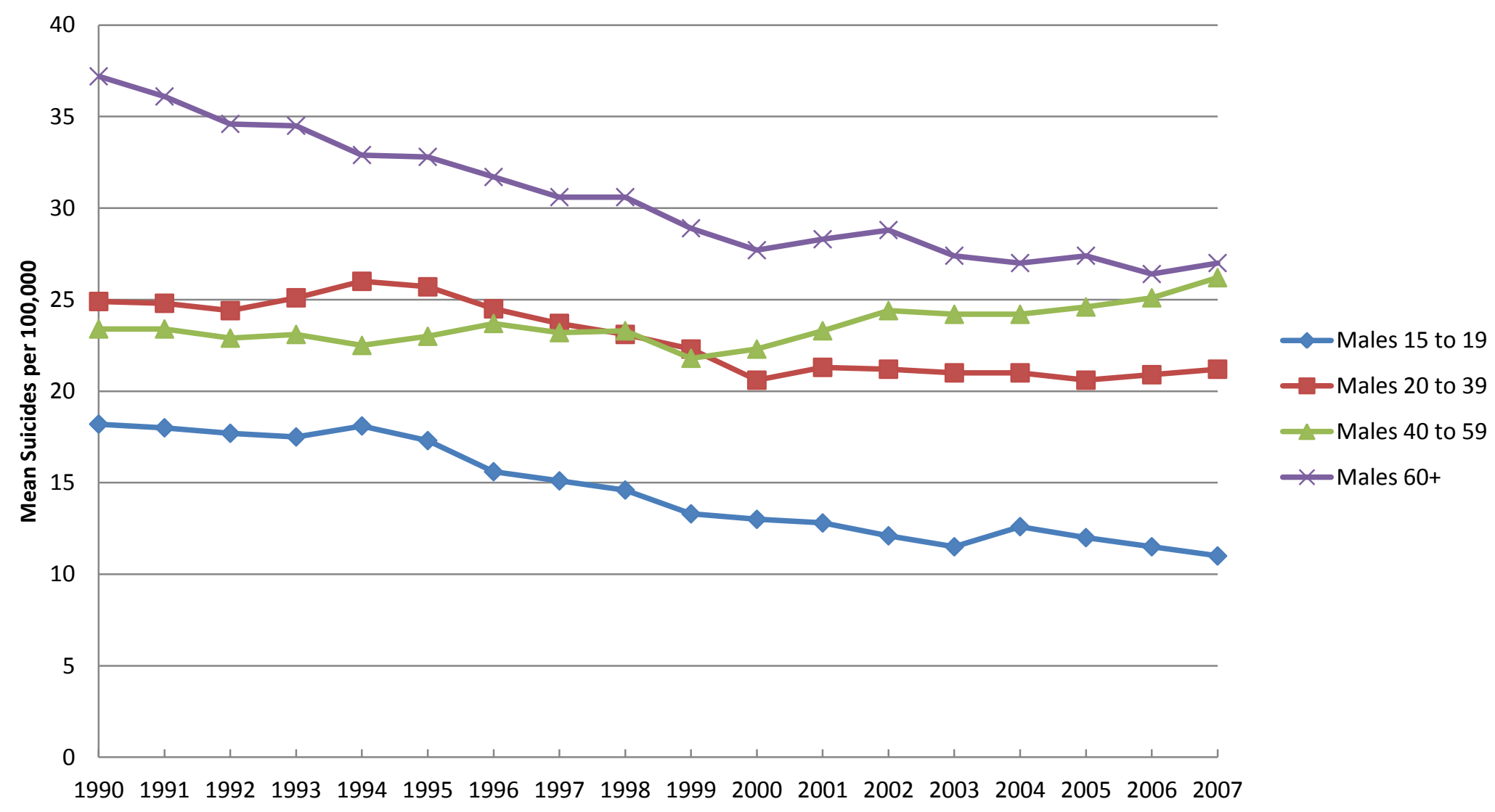




\section{Figure 3. National Suicide Rates by Age, Females}

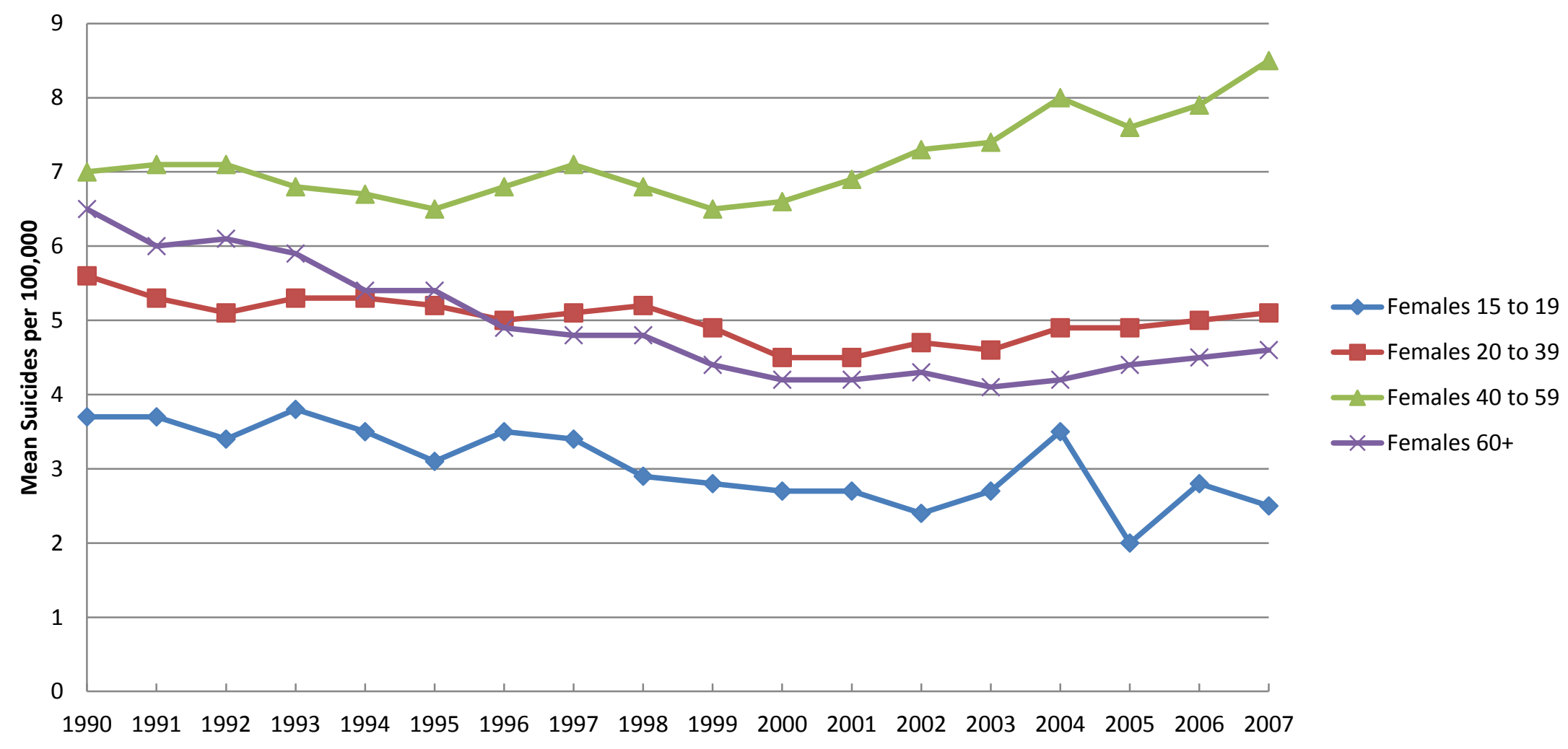


Figure 4. Pre- and Post-Legalization Trends in Suicide Rates, Total

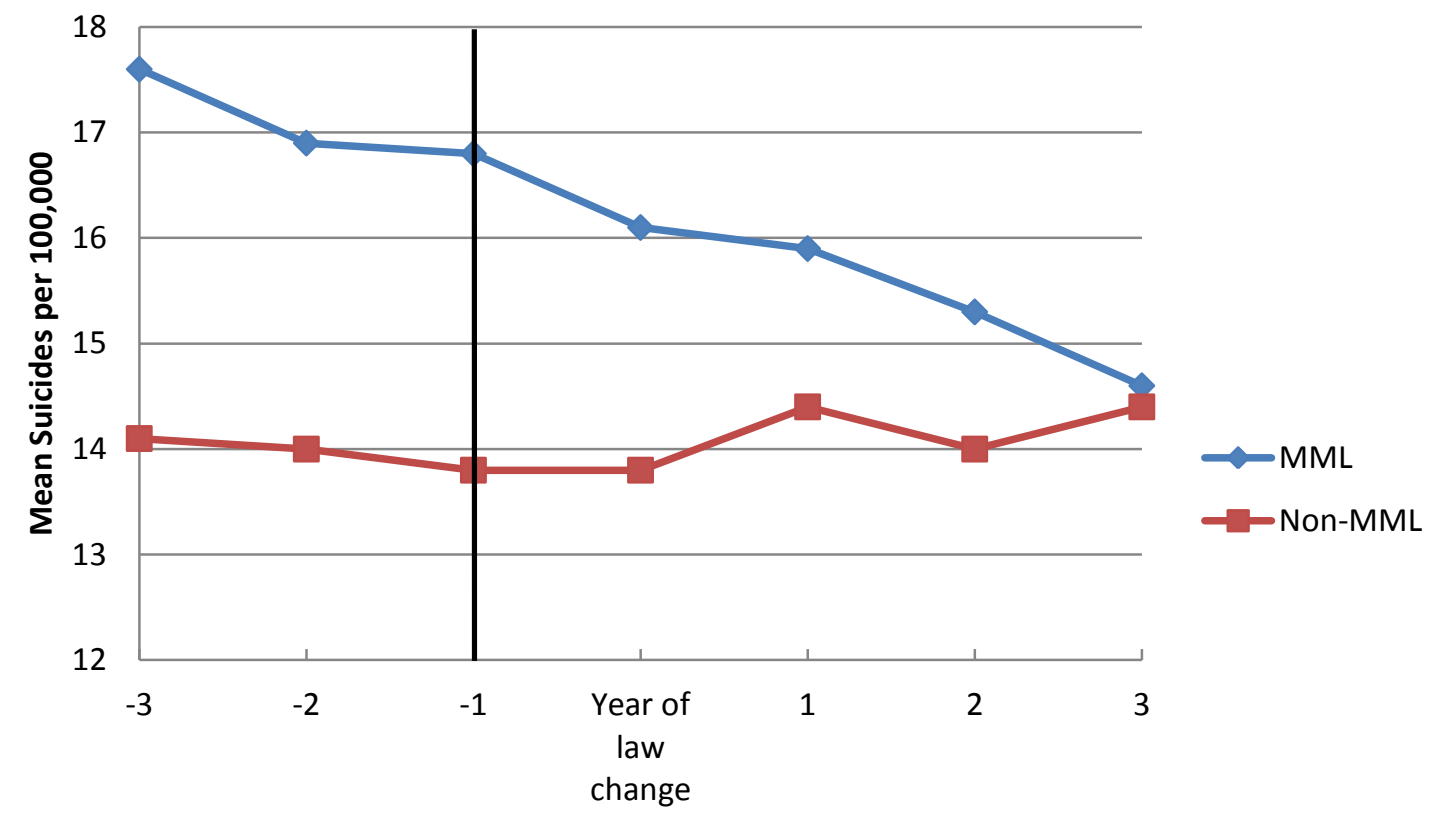

On the horizontal axis, 0 represents the year in which medical marijuana was legalized. It was randomly assigned to states that did not legalize medical marijuana during the period under study (1990-2007). 
Figure 5. Pre- and Post-Legalization Trends in Suicide Rates, Males

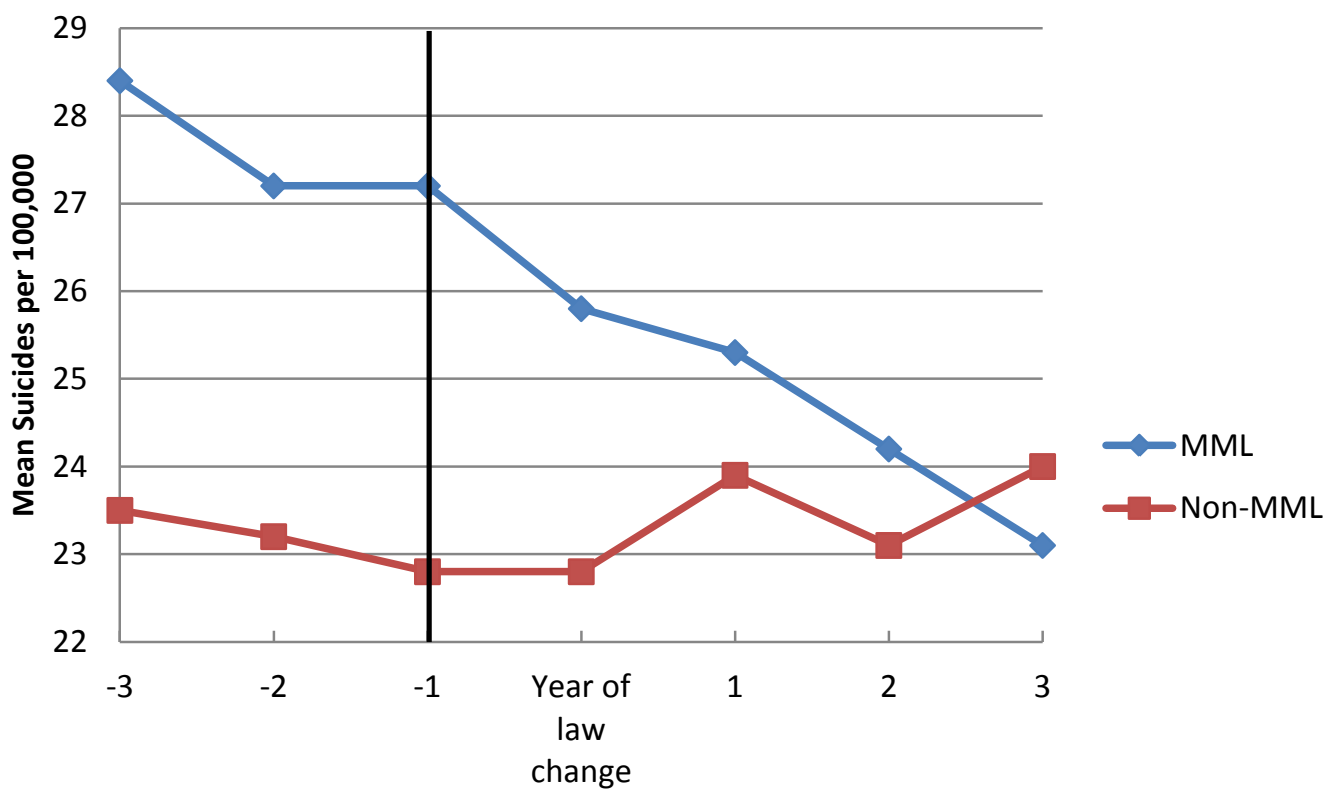

On the horizontal axis, 0 represents the year in which medical marijuana was legalized. It was randomly assigned to states that did not legalize medical marijuana during the period under study (1990-2007). 
Figure 6. Pre- and Post-Legalization Trends in Suicide Rates, Females

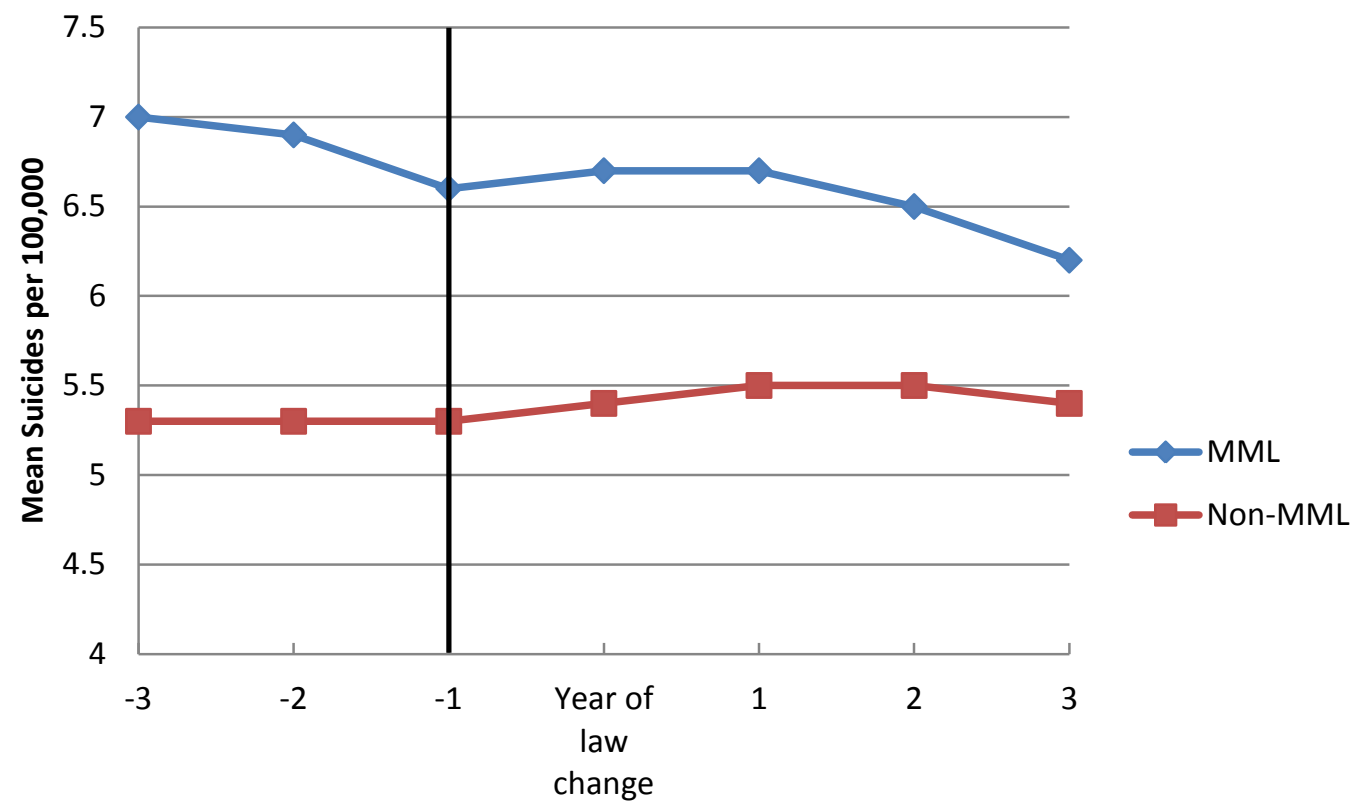

On the horizontal axis, 0 represents the year in which medical marijuana was legalized. It was randomly assigned to states that did not legalize medical marijuana during the period under study (1990-2007). 
Figure 7. Pre- and Post-Legalization Trends in Suicide Rates, Males 15 to 19 years-old

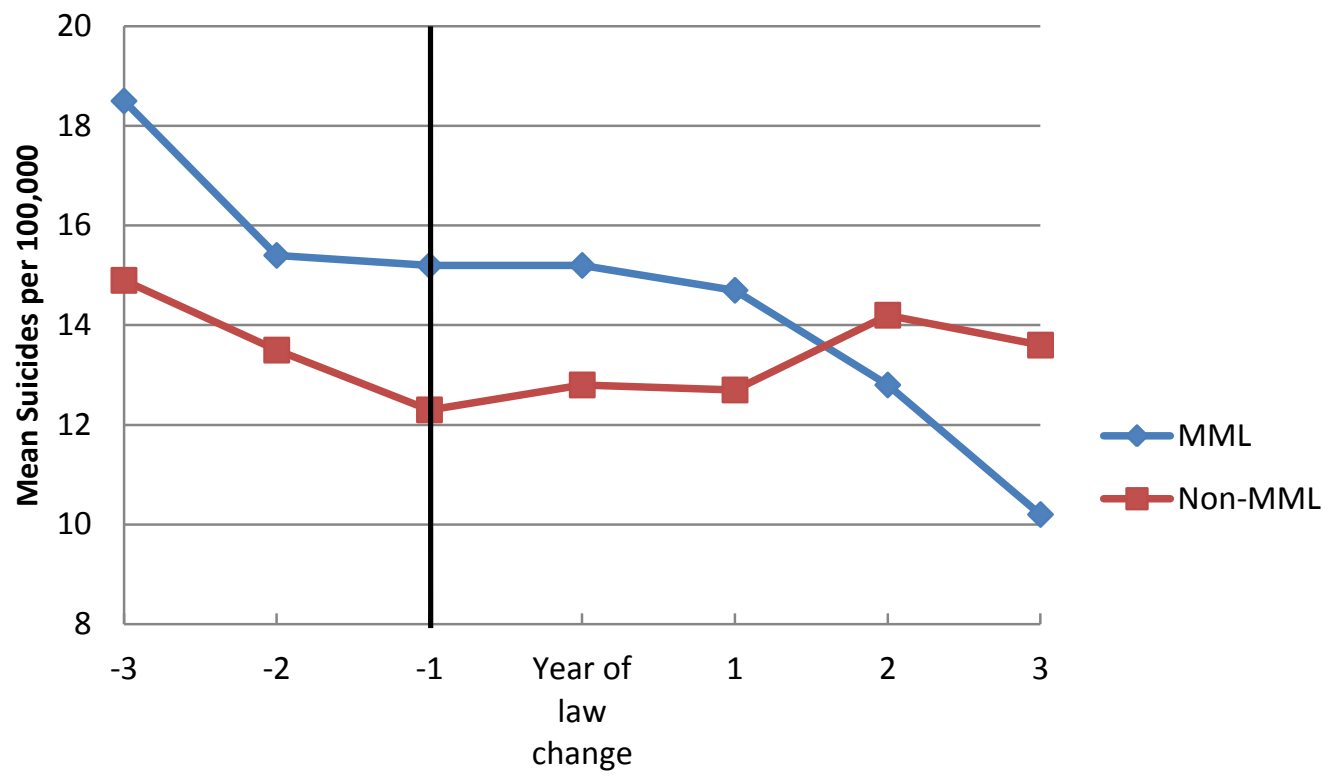

On the horizontal axis, 0 represents the year in which medical marijuana was legalized. It was randomly assigned to states that did not legalize medical marijuana during the period under study (1990-2007). 
Figure 8. Pre- and Post-Legalization Trends in Suicide Rates, Males 20 to 39 years-old

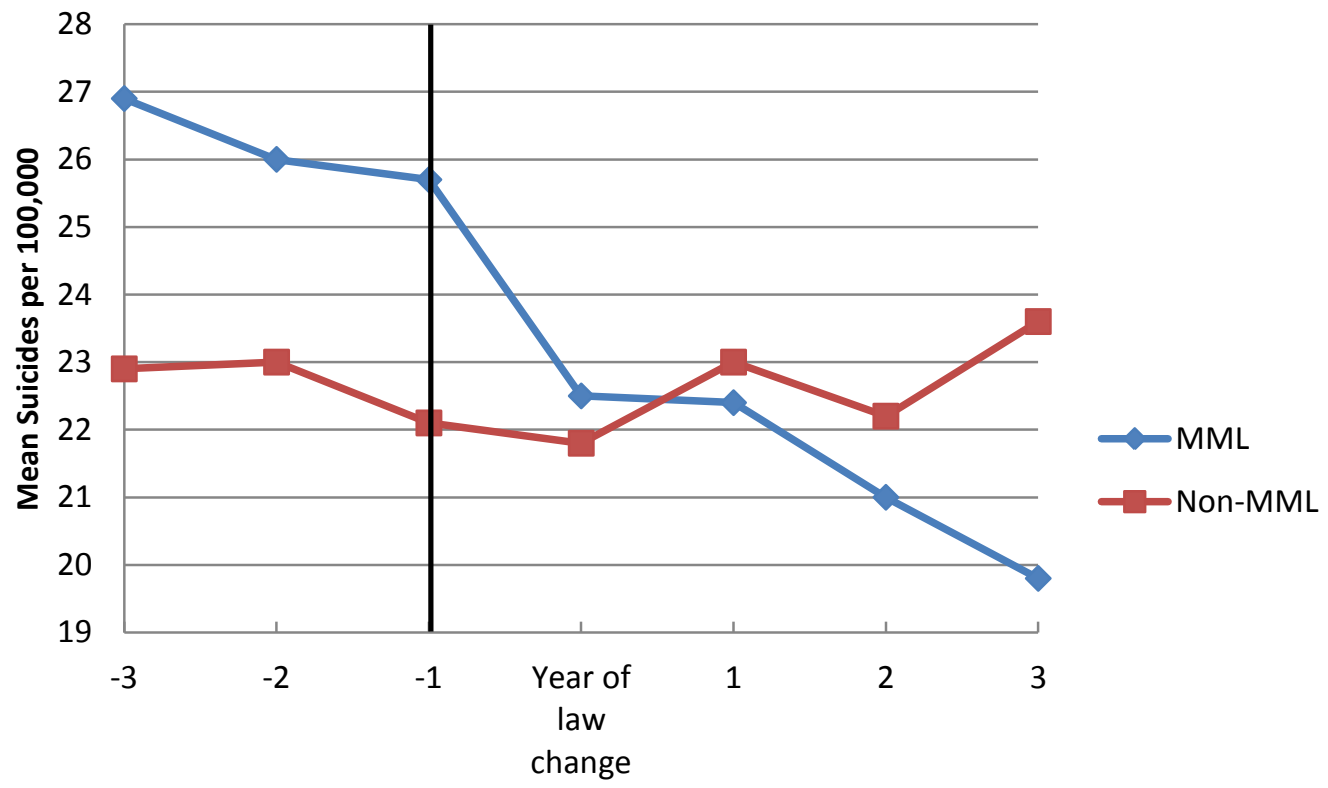

On the horizontal axis, 0 represents the year in which medical marijuana was legalized. It was randomly assigned to states that did not legalize medical marijuana during the period under study (1990-2007). 
Figure 9. Pre- and Post-Legalization Trends in Suicide Rates, Males $\mathbf{4 0}$ to 59 years-old

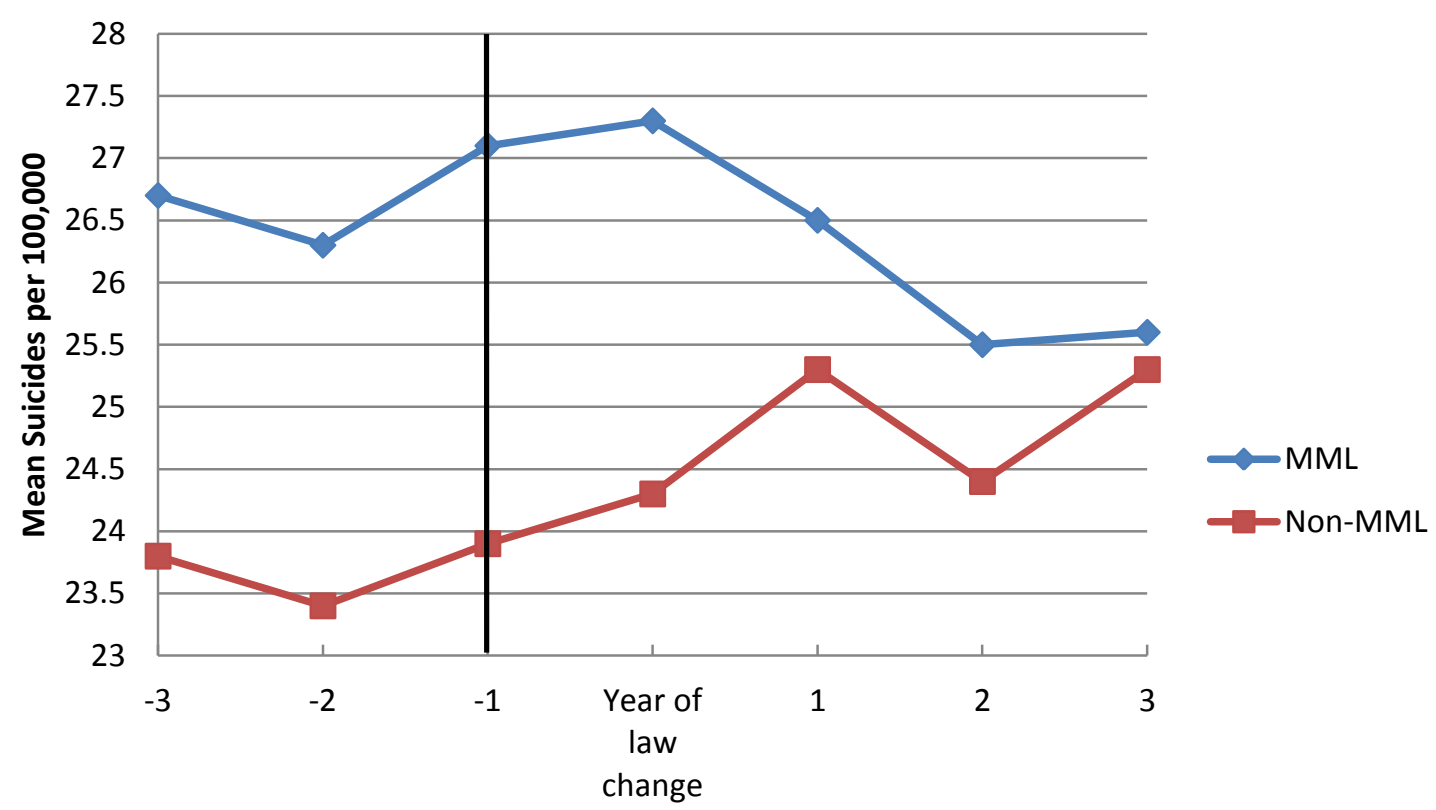

On the horizontal axis, 0 represents the year in which medical marijuana was legalized. It was randomly assigned to states that did not legalize medical marijuana during the period under study (1990-2007). 
Figure 10. Pre- and Post-Legalization Trends in Suicide Rates, Males $60+$ years-old

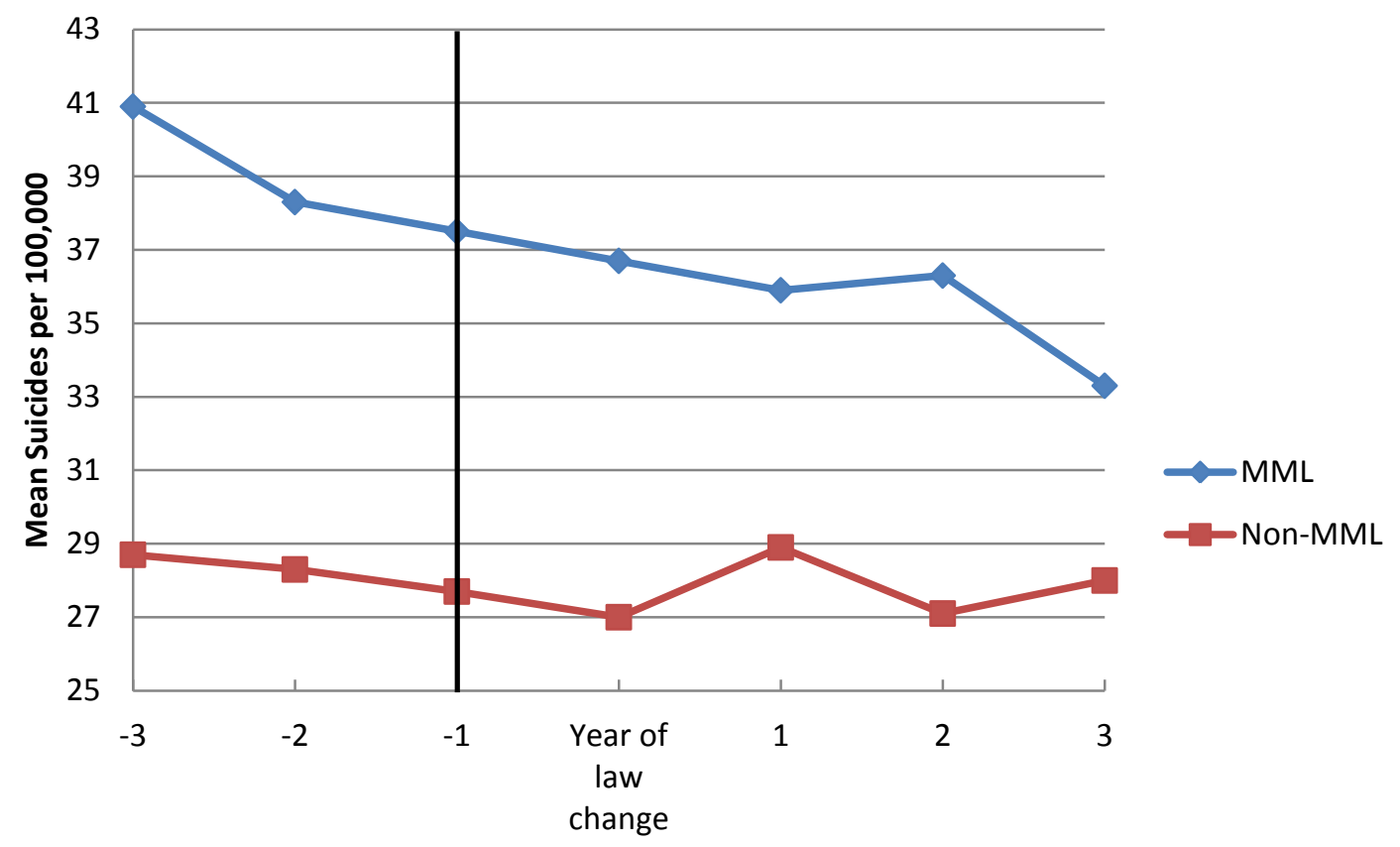

On the horizontal axis, 0 represents the year in which medical marijuana was legalized. It was randomly assigned to states that did not legalize medical marijuana during the period under study (1990-2007). 
Figure 11. Pre- and Post-Legalization Trends in Suicide Rates, Females 15 to 19 years-old

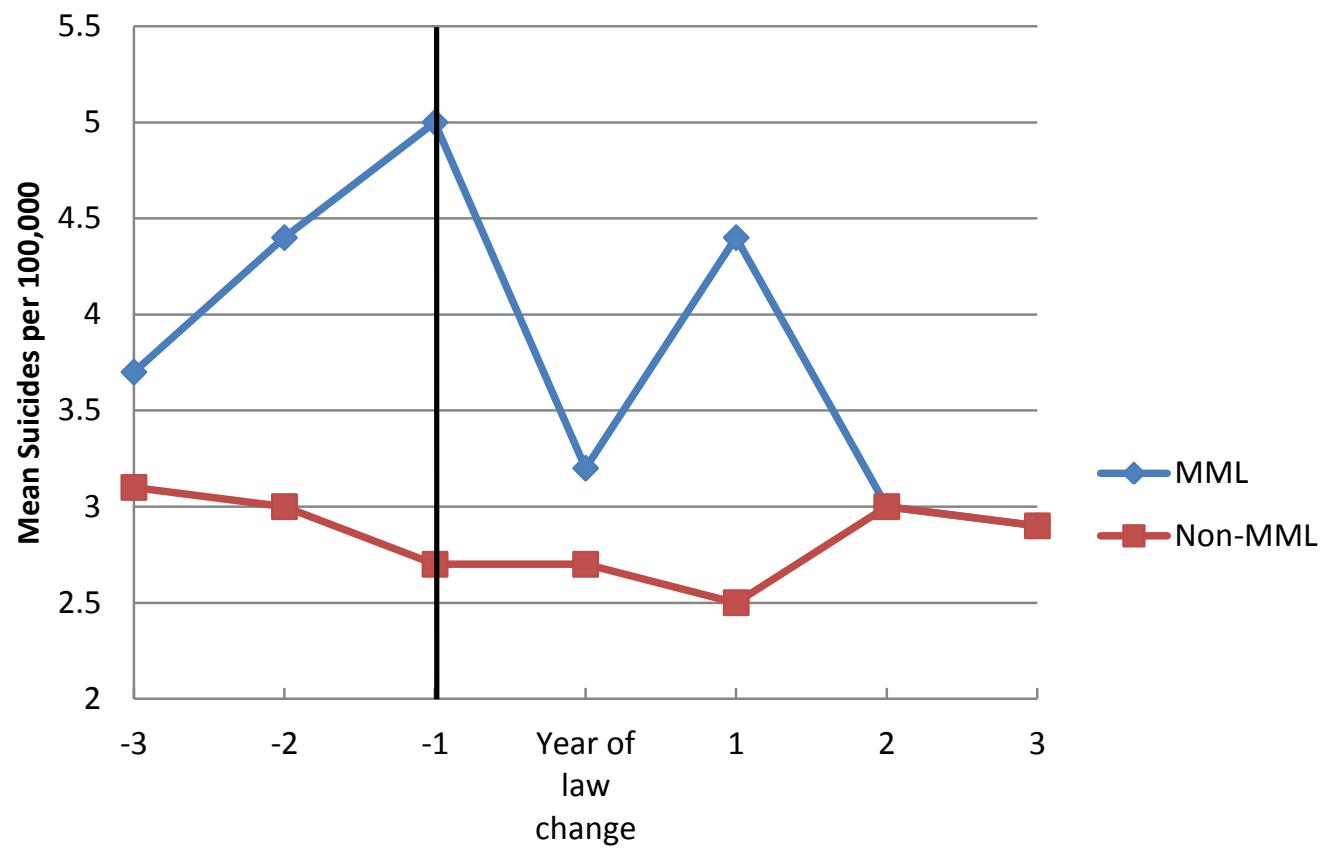

On the horizontal axis, 0 represents the year in which medical marijuana was legalized. It was randomly assigned to states that did not legalize medical marijuana during the period under study (1990-2007). 
Figure 12. Pre- and Post-Legalization Trends in Suicide Rates, Females 20 to 39 years-old

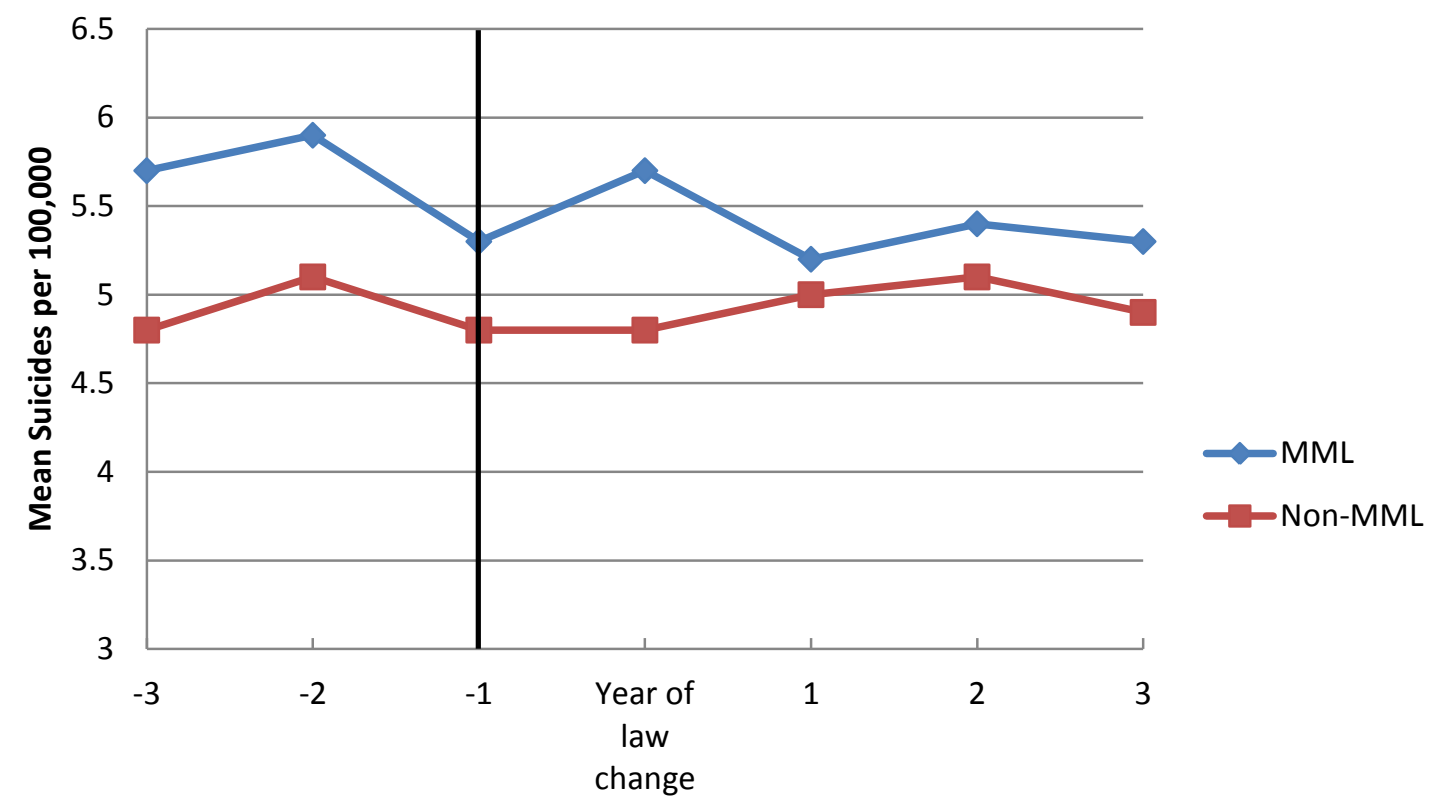

On the horizontal axis, 0 represents the year in which medical marijuana was legalized. It was randomly assigned to states that did not legalize medical marijuana during the period under study (1990-2007). 
Figure 13. Pre- and Post-Legalization Trends in Suicide Rates, Females 40 to 59 years-old

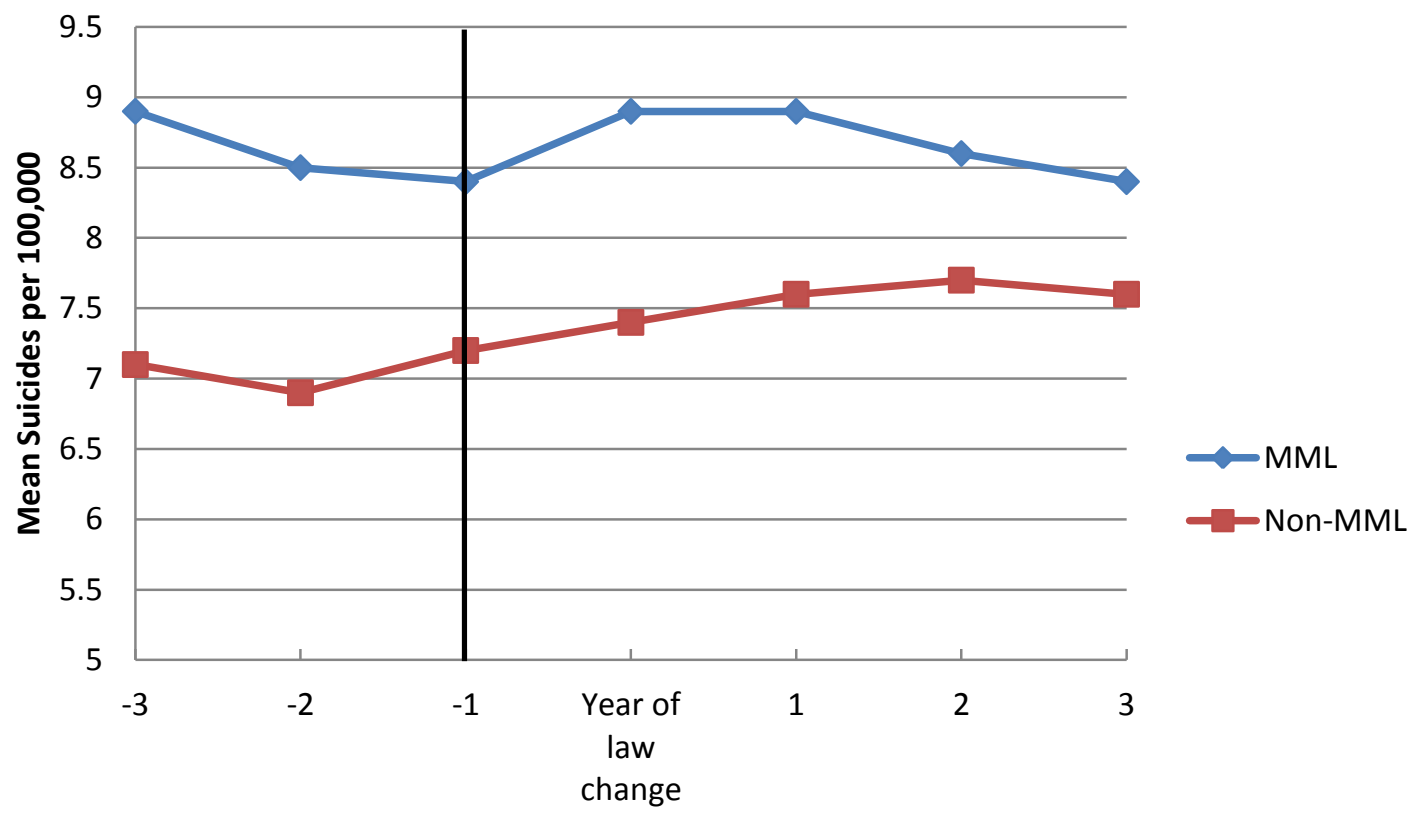

On the horizontal axis, 0 represents the year in which medical marijuana was legalized. It was randomly assigned to states that did not legalize medical marijuana during the period under study (1990-2007). 
Figure 14. Pre- and Post-Legalization Trends in Suicide Rates, Females $60+$ years-old

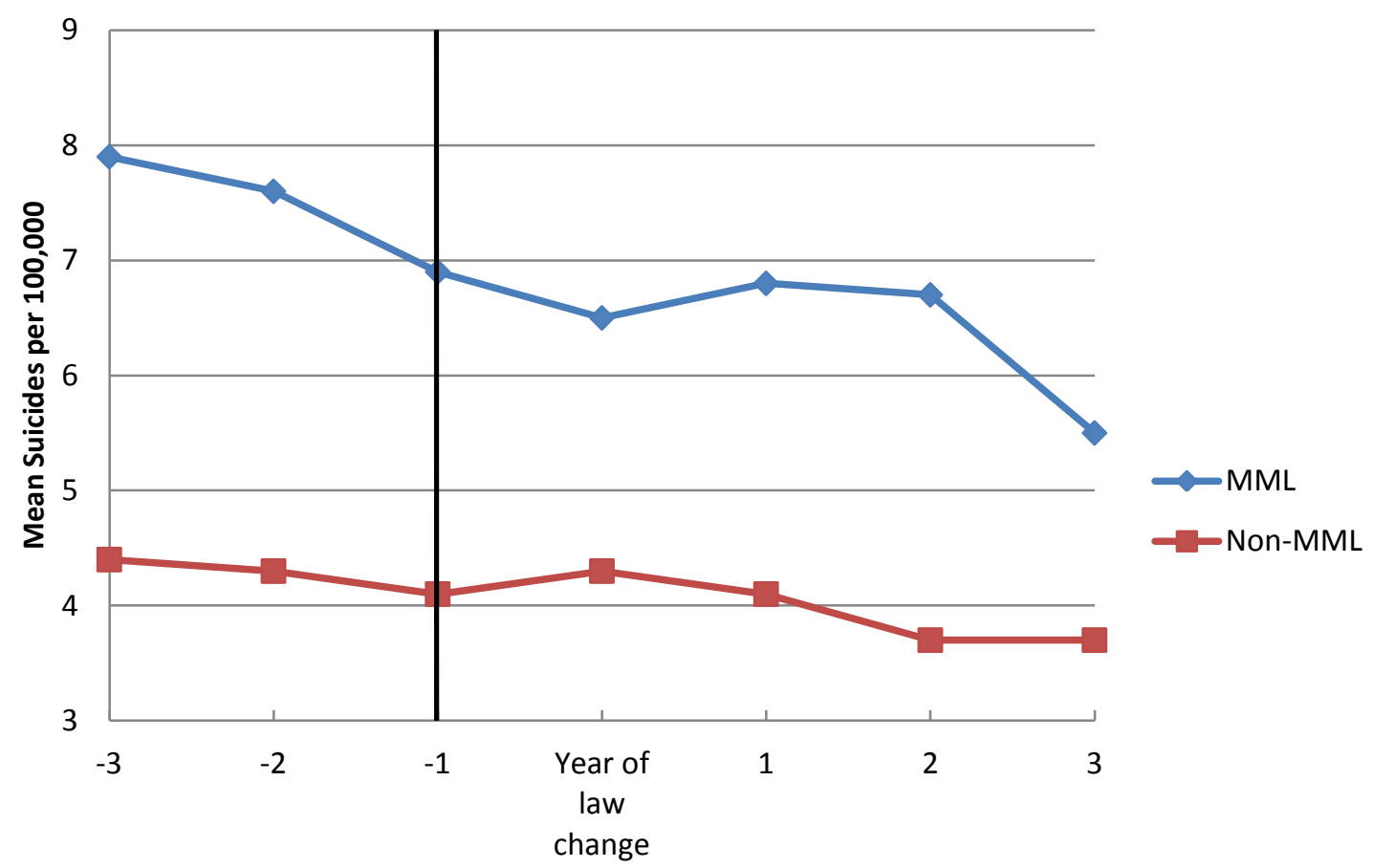

On the horizontal axis, 0 represents the year in which medical marijuana was legalized. It was randomly assigned to states that did not legalize medical marijuana during the period under study (1990-2007). 


\section{Dependent Variables}

Suicide rates per 100,000

Suicides Total

Suicides Male

Ages 15-19

Ages 20-29

Ages 30-39

Ages 40-49

Ages 50-59

Ages 60+

Suicides Female

Ages 15-19

Ages 20-29

Ages 30-39

Ages 40-49

Ages 50-59

Ages 60+

\section{Independent Variables}

Medical Marijuana Law

Marijuana Decriminalization Law

Ln (State Income)

Unemployment Rate

Blood Alcohol Content 0.08

Zero Tolerance Law

Real Beer Tax (2000 dollars)

\section{$\underline{\text { Mean (SD) }}$}

$14.3(3.47)$

$23.7(5.72)$

$14.4(6.13)$

$22.9(6.92)$

$22.9(6.27)$

$24.0(6.19)$

$23.3(6.10)$

$30.3(8.81)$

$5.51(1.49)$

$3.09(1.82)$

$4.13(1.53)$

$5.79(2.00)$

$7.35(2.59)$

$6.97(2.43)$

4.89 (1.90)
$0.111(0.311)$

0.327 (0.469)

$10.3(0.153)$

$5.43(1.36)$

$0.509(0.491)$

$0.721(0.440)$

$0.252(0.214)$

$\mathrm{N}$

918 
Table 2. Estimates of Relationship between Medical Marijuana Laws and the Natural Log of the Suicide Rate

\begin{tabular}{lccc}
\hline & Suicides Total & Suicides Male & Suicides Female \\
\hline Year/State FEs & $-0.084^{*}$ & $-0.073^{*}$ & -0.106 \\
& $(0.050)$ & $(0.043)$ & $(0.070)$ \\
& {$[0.94]$} & {$[0.94]$} & {$[0.82]$} \\
Year/State FEs and & $-0.072^{* *}$ & $-0.065^{* * *}$ & -0.080 \\
Covariates & $(0.036)$ & $(0.031)$ & $(0.050)$ \\
& {$[0.94]$} & {$[0.94]$} & {$[0.83]$} \\
Year/State FEs, & $-0.049^{*}$ & $-0.047^{* *}$ & -0.060 \\
Covariates, and State & $(0.025)$ & $(0.021)$ & $(0.042)$ \\
Trends & {$[0.96]$} & {$[0.96]$} & {$[0.87]$} \\
Observations & 918 & 918 & 918 \\
\hline
\end{tabular}

***Statistically significant at the $1 \%$ level; **at the $5 \%$ level; *at the $1 \%$ level.

Each cell represents the results from a separate regression. The dependent variable is equal to the natural $\log$ of the suicide rate per 100,000 population, and is based on information collected from the Centers for Disease Control for the period 1990-2007; the covariates are listed in Table 1. Regressions are weighted using the relevant state-by-sex populations. Standard errors, corrected for clustering at the state level, are in parentheses and $\mathrm{R}^{2} \mathrm{~s}$ are in brackets. 
Table 3. Estimates of Relationship between Medical Marijuana Laws and the Natural Log of the Male Suicide Rate by Age Group

\begin{tabular}{|c|c|c|c|c|c|c|}
\hline & $\begin{array}{c}15-19 \\
\text { yr.-olds }\end{array}$ & $\begin{array}{c}20-29 \\
\text { yr.-olds }\end{array}$ & $\begin{array}{c}30-39 \\
\text { yr.-olds }\end{array}$ & $\begin{array}{c}40-49 \\
\text { yr.-olds }\end{array}$ & $\begin{array}{c}50-59 \\
\text { yr.-olds }\end{array}$ & $\begin{array}{c}60+ \\
\text { yr.-olds }\end{array}$ \\
\hline Year/State FEs & $\begin{array}{c}-0.077 \\
(0.077) \\
{[0.72]}\end{array}$ & $\begin{array}{c}-0.096^{* * *} \\
(0.025) \\
{[0.85]}\end{array}$ & $\begin{array}{c}-0.147^{* * *} \\
(0.048) \\
{[0.82]}\end{array}$ & $\begin{array}{c}-0.129 \\
(0.083) \\
{[0.78]}\end{array}$ & $\begin{array}{c}-0.030 \\
(0.062) \\
{[0.72]}\end{array}$ & $\begin{array}{c}-0.008 \\
(0.037) \\
{[0.89]}\end{array}$ \\
\hline $\begin{array}{l}\text { Year/State FEs } \\
\text { and Covariates }\end{array}$ & $\begin{array}{c}-0.091 \\
(0.080) \\
{[0.72]}\end{array}$ & $\begin{array}{c}-0.096^{* * *} \\
(0.022) \\
{[0.85]}\end{array}$ & $\begin{array}{c}-0.129^{* * *} \\
(0.032) \\
{[0.83]}\end{array}$ & $\begin{array}{c}-0.113^{* *} \\
(0.054) \\
{[0.80]}\end{array}$ & $\begin{array}{c}-0.010 \\
(0.045) \\
{[0.73]}\end{array}$ & $\begin{array}{r}-0.010 \\
(0.034) \\
{[0.90]}\end{array}$ \\
\hline $\begin{array}{l}\text { Year/State FEs, } \\
\text { Covariates, and } \\
\text { State Trends }\end{array}$ & $\begin{array}{c}-0.118 \\
(0.114) \\
{[0.75]}\end{array}$ & $\begin{array}{c}-0.114^{* * *} \\
(0.077) \\
{[0.87]}\end{array}$ & $\begin{array}{c}-0.099^{* * *} \\
(0.037) \\
{[0.86]}\end{array}$ & $\begin{array}{c}-0.060 \\
(0.043) \\
{[0.84]}\end{array}$ & $\begin{array}{c}-0.015 \\
(0.041) \\
{[0.77]}\end{array}$ & $\begin{array}{c}0.036 \\
(0.028) \\
{[0.91]}\end{array}$ \\
\hline Observations & 918 & 918 & 918 & 918 & 918 & 918 \\
\hline
\end{tabular}

*** Statistically significant at the $1 \%$ level; **at the 5\% level; *at the $1 \%$ level.

Each cell represents the results from a separate regression. The dependent variable is equal to the natural log of the suicide rate per 100,000 population, and is based on information collected from the Centers for Disease Control for the period 1990-2007; the covariates are listed in Table 1. Regressions are weighted using the relevant state-by-age populations. Standard errors, corrected for clustering at the state level, are in parentheses and $\mathrm{R}^{2} \mathrm{~s}$ are in brackets. 
Table 4. Estimates of Relationship between Medical Marijuana Laws and the Natural Log of the Female Suicide Rate by Age Group

\begin{tabular}{lcccccc}
\hline & & & & & & \\
& $\begin{array}{c}15-19 \\
\text { yr.-olds }\end{array}$ & $\begin{array}{c}20-29 \\
\text { yr.-olds }\end{array}$ & $\begin{array}{c}30-39 \\
\text { yr.-olds }\end{array}$ & $\begin{array}{c}40-49 \\
\text { yr.-olds }\end{array}$ & $\begin{array}{c}50-59 \\
\text { yr.-olds }\end{array}$ & $\begin{array}{c}60+ \\
\text { yr.-olds }\end{array}$ \\
\hline Year/State FEs & -0.069 & -0.062 & $-0.125^{* *}$ & -0.120 & -0.068 & -0.082 \\
& $(0.159)$ & $(0.061)$ & $(0.059)$ & $(0.106)$ & $(0.103)$ & $(0.062)$ \\
& {$[0.29]$} & {$[0.40]$} & {$[0.53]$} & {$[0.64]$} & {$[0.50]$} & {$[0.63]$} \\
Year/State FEs & -0.105 & -0.044 & $-0.110^{* *}$ & -0.078 & -0.019 & -0.082 \\
and Covariates & $(0.165)$ & $(0.065)$ & $(0.054)$ & $(0.066)$ & $(0.072)$ & $(0.057)$ \\
& {$[0.30]$} & {$[0.40]$} & {$[0.53]$} & {$[0.65]$} & {$[0.51]$} & {$[0.63]$} \\
Year/State FEs, & 0.083 & -0.008 & -0.035 & -0.041 & $-0.104^{*}$ & $-0.121^{* *}$ \\
Covariates, and & $(0.235)$ & $(0.065)$ & $(0.088)$ & $(0.055)$ & $(0.060)$ & $(0.059)$ \\
State Trends & {$[0.34]$} & {$[0.45]$} & {$[0.59]$} & {$[0.71]$} & {$[0.55]$} & {$[0.65]$} \\
Observations & 918 & 918 & 918 & 918 & 918 & 918 \\
\hline
\end{tabular}

***Statistically significant at the $1 \%$ level; **at the $5 \%$ level; *at the $1 \%$ level.

Each cell represents the results from a separate regression. The dependent variable is equal to the natural $\log$ of the suicide rate per 100,000 population, and is based on information collected from the Centers for Disease Control for the period 1990-2007; the covariates are listed in Table 1. Regressions are weighted using the relevant state-by-age populations. Standard errors, corrected for clustering at the state level, are in parentheses and $R^{2} \mathrm{~s}$ are in brackets. 
Table 5. Estimates of Relationship between Medical Marijuana Laws and the Natural Log of the Suicide Rate: Adding Leads and Lags to the Model

\begin{tabular}{|c|c|c|c|}
\hline & Suicides Total & Suicides Male & Suicides Female \\
\hline 2-3 years before MML & $\begin{array}{c}-0.020 \\
(0.015)\end{array}$ & $\begin{array}{c}-0.006 \\
(0.018)\end{array}$ & $\begin{array}{l}-0.066^{*} \\
(0.033)\end{array}$ \\
\hline 1-2 years before MML & $\begin{array}{c}-0.023 \\
(0.021)\end{array}$ & $\begin{array}{c}-0.002 \\
(0.010)\end{array}$ & $\begin{array}{l}-0.106^{* * * *} \\
(0.036)\end{array}$ \\
\hline 0-1 year before $\mathrm{MML}$ & $\begin{array}{c}-0.045^{* *} \\
(0.017)\end{array}$ & $\begin{array}{c}-0.018 \\
(0.019)\end{array}$ & $\begin{array}{c}-0.140^{* *} \\
(0.053)\end{array}$ \\
\hline Year of law change & $\begin{array}{c}-0.085^{* * *} \\
(0.029)\end{array}$ & $\begin{array}{c}-0.066^{* *} \\
(0.022)\end{array}$ & $\begin{array}{c}-0.154^{* *} \\
(0.058)\end{array}$ \\
\hline $0-1$ year after MML & $\begin{array}{l}-0.063^{*} \\
(0.034)\end{array}$ & $\begin{array}{c}-0.043 \\
(0.027)\end{array}$ & $\begin{array}{l}-0.138^{*} \\
(0.070)\end{array}$ \\
\hline 1-2 years after MML & $\begin{array}{c}-0.098^{* * *} \\
(0.029)\end{array}$ & $\begin{array}{c}-0.080^{* * *} \\
(0.021)\end{array}$ & $\begin{array}{c}-0.160^{* *} \\
(0.062)\end{array}$ \\
\hline 2-3 years after MML & $\begin{array}{c}-0.154^{* * *} \\
(0.035)\end{array}$ & $\begin{array}{c}-0.124^{* * *} \\
(0.023)\end{array}$ & $\begin{array}{c}-0.257^{* * *} \\
(0.094)\end{array}$ \\
\hline $3+$ years after MML & $\begin{array}{c}-0.174^{* * *} \\
(0.052)\end{array}$ & $\begin{array}{c}-0.129^{* * *} \\
(0.032)\end{array}$ & $\begin{array}{c}-0.327^{* *} \\
(0.124)\end{array}$ \\
\hline Year FE & yes & yes & yes \\
\hline State FE & yes & yes & yes \\
\hline Covariates & yes & yes & yes \\
\hline State Trends & yes & yes & yes \\
\hline $\mathrm{R}^{2}$ & 0.97 & 0.96 & 0.87 \\
\hline Observations & 918 & 918 & 918 \\
\hline
\end{tabular}

***Statistically significant at the $1 \%$ level; **at the $5 \%$ level; *at the $1 \%$ level.

Each cell represents the results from a separate regression. The dependent variable is equal to the natural $\log$ of the suicide rate per 100,000 population, and is based on information collected from the Centers for Disease Control for the period 1990-2007; the covariates are listed in Table 1. Regressions are weighted using the relevant state-by-sex populations. Standard errors, corrected for clustering at the state level, are in parentheses and $\mathrm{R}^{2} \mathrm{~s}$ are in brackets. 
Table 6: The Average Effect of Randomly Assigned MMLs on Suicide Rates

\begin{tabular}{lccc} 
& Suicides Total & Suicides Male & Suicides Female \\
\hline Average MML estimate & $\begin{array}{l}-0.002 \\
(0.020)\end{array}$ & -0.001 & -0.009 \\
& & $(0.017)$ & $(0.038)$ \\
Number of trials & 50 & 50 & 50 \\
Number of negative MML & 30 & 29 & 31 \\
coefficients & & & \\
$\begin{array}{l}\text { Number of } M M L \text { estimates } \\
\text { that were negative and }\end{array}$ & 4 & 3 & 4 \\
significant at 5\% level & & & \\
$\begin{array}{l}\text { Year FE } \\
\text { State FE }\end{array}$ & Yes & Yes & \\
$\begin{array}{l}\text { Covariates } \\
\text { State Trends }\end{array}$ & Yes & Yes & Yes \\
\hline
\end{tabular}

$*$ Statistically significant at $10 \%$ level; ** at $5 \%$ level; *** at $1 \%$ level.

Notes: Each column represents the results from a series of regressions. Average standard errors, corrected for clustering at the state-level, are in parentheses. 
Effective date

\begin{tabular}{ll}
\hline Alaska & March 4, 1999 \\
California & November 6, 1996 \\
Colorado & June 1, 2001 \\
Hawaii & December 28, 2000 \\
Maine & December 22, 1999 \\
Montana & November 2, 2004 \\
Nevada & October 1, 2001 \\
New Mexico & July 1, 2007 \\
Oregon & December 3, 1998 \\
Rhode Island & January 3, 2006 \\
Vermont & July 1, 2004 \\
Washington & November 3, 1998 \\
\hline
\end{tabular}

Notes: Arizona, D.C., Delaware, Michigan, and New Jersey have passed medical marijuana laws since 2007. Source: Eddy (2010). 


\begin{tabular}{|c|c|c|c|c|c|c|}
\hline 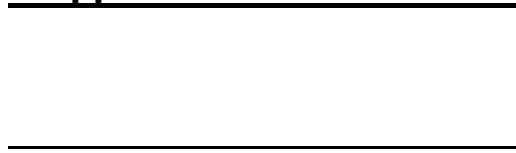 & $\begin{array}{c}(1) \\
18-19 \\
\text { yr.-olds }\end{array}$ & $\begin{array}{c}(2) \\
20-29 \\
\text { yr.-olds }\end{array}$ & $\begin{array}{c}(3) \\
30-39 \\
\text { yr.-olds }\end{array}$ & $\begin{array}{c}(4) \\
40-49 \\
\text { yr.-olds }\end{array}$ & $\begin{array}{c}(5) \\
50-59 \\
\text { yr.-olds }\end{array}$ & $\begin{array}{c}(6) \\
60+ \\
\text { yr.-olds }\end{array}$ \\
\hline $\begin{array}{l}\text { Number of Drinks (Males) } \\
\text { MML }\end{array}$ & $-18.7 \%$ & $-21.6 \%{ }^{* *}$ & $-2.53 \%$ & $-4.70 \%$ & $-3.74 \%$ & $-3.07 \%$ \\
\hline Observations & 852 & 852 & 852 & 852 & 852 & 852 \\
\hline $\begin{array}{l}\text { Number of Drinks (Females) } \\
\text { MML }\end{array}$ & $5.26 \%$ & $-21.0 \%{ }^{* *}$ & $-10.3 \% *$ & $-12.6 \%{ }^{* *}$ & $-5.43 \%$ & $-12.2 \%$ \\
\hline Observations & 855 & 855 & 855 & 855 & 855 & 855 \\
\hline $\begin{array}{l}\text { Year FE } \\
\text { State FE } \\
\text { Covariates } \\
\text { State-specific trends }\end{array}$ & $\begin{array}{l}\text { Yes } \\
\text { Yes } \\
\text { Yes } \\
\text { Yes } \\
\end{array}$ & $\begin{array}{l}\text { Yes } \\
\text { Yes } \\
\text { Yes } \\
\text { Yes }\end{array}$ & $\begin{array}{l}\text { Yes } \\
\text { Yes } \\
\text { Yes } \\
\text { Yes }\end{array}$ & $\begin{array}{l}\text { Yes } \\
\text { Yes } \\
\text { Yes } \\
\text { Yes }\end{array}$ & $\begin{array}{l}\text { Yes } \\
\text { Yes } \\
\text { Yes } \\
\text { Yes } \\
\end{array}$ & $\begin{array}{l}\text { Yes } \\
\text { Yes } \\
\text { Yes } \\
\text { Yes }\end{array}$ \\
\hline
\end{tabular}

*Statistically significant at $10 \%$ level; **at $5 \%$ level; ***at $1 \%$ level.

Notes: Each column represents the results from a separate regression. The dependent variable is the mean number of drinks consumed in the past 30 days in state $s$ and year $t$, and is based on information collected from the Behavioral Risk Factor Surveillance System (BRFSS) for the period 1990-2009. Controls include the state unemployment rate, per capita income, the relevant population size (e.g., the number of males or females in state $s$ and year $t$ ), the state beer tax, and indicators for marijuana decriminalization, BAC 0.08 , administrative license revocation, and Zero Tolerance. Regressions are weighted using sample sizes from the BRFSS. Standard errors, corrected for clustering at the state level, are in parentheses. 


\section{Appendix Table 3. Alcohol Sales and Medical Marijuana Laws: Summary of}

Results from Anderson et al. (2011)

(1)

State-level per

capita beer sales (1990-2009)

\section{(2)}

State-level per

capita wine sales (1994-2009)
(3)

State-level per

capita spirits sales (1994-2009)

$\begin{array}{llll}\text { MML } & -5.3 \% * * * & -1.2 \% & -0.2 \%\end{array}$

Observations

1020

816

816

Year FE

Yes

Yes

Yes

State FE

Yes

Yes

Yes

State covariates

Yes

Yes

Yes

Yes

Yes

*Statistically significant at $10 \%$ level; **at $5 \%$ level; ***at $1 \%$ level.

Notes: Each column represents the results from a separate regression. The dependent variable is equal to the natural log of per capita sales (measured in gallons) and is based on data from the Brewers Almanac, published by the Beer Institute. Controls include the state unemployment rate, per capita income, the state beer tax, and indicators for marijuana decriminalization, BAC 0.08, administrative license revocation, and Zero Tolerance. Regressions are weighted using state populations. Standard errors, corrected for clustering at the state level, are in parentheses. 